\title{
Labor Market Reforms, Growth, and Unemployment in Labor-Exporting Countries in the Middle East and North Africa
}

\author{
Pierre-Richard Agénor,* Mustapha K. Nabli,* \\ Tarik Yousef,** and Henning Tarp Jensen***
}

\begin{abstract}
This paper studies the impact of labor market policies on growth and unemployment in labor-exporting countries in the Middle East and North Africa. The analysis is based on a framework that captures many of the main features of the labor market in these countries. We conduct a variety of policy experiments, including a reduction in payroll taxation, cuts in public sector wages and employment, an increase in employment subsidies, a reduction in trade unions' bargaining power, and a composite reform program. Our key message is that to foster broad-based growth and job creation in the region, labor market reforms must not be viewed in isolation but rather as a component of a comprehensive program of structural reforms.
\end{abstract}

JEL Classification Numbers: C68, D58, O11

\footnotetext{
${ }^{*}$ World Bank, Washington DC 20433; ${ }^{* *}$ Georgetown University; and ${ }^{* * *}$ University of Copenhagen, Denmark. We are grateful to various colleagues for helpful comments on a preliminary version. The views expressed in this paper do not necessarily represent those of the World Bank.
} 


\section{Contents}

1 Introduction 3

2 Some Basic Facts $\quad 5$

3 A Formal Framework $\quad 8$

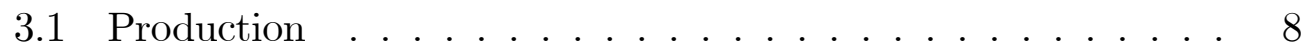

3.2 The Labor Market . . . . . . . . . . . . . . . . . . . . . . . . . 9

3.3 The Pay-as-you-go Pension System . . . . . . . . . . . . 17

3.4 Other Model Features . . . . . . . . . . . . . . . . . . 19

4 Calibration and Parameter Values $\quad 22$

4.1 The Social Accounting Matrix . . . . . . . . . . . . . . 23

4.2 Behavioral Parameters . . . . . . . . . . . . . . 24

5 Simulation Experiments $\mathbf{2 5}$

5.1 Reduction in Payroll Taxes on Unskilled Labor . . . . . . . . . 25

5.2 Cut in Public Sector Wages . . . . . . . . . . . . . . 28

5.3 Public Sector Layoffs . . . . . . . . . . . . . . . . . . . . . . . . . . . 30

5.4 Subsidies to Private Employment . . . . . . . . . . . . . 32

5.5 Reduction in Unions' Bargaining Strength . . . . . . . . . . 34

5.6 A Composite Reform Program . . . . . . . . . . . . . 35

6 Summary and Policy Lessons 36

Appendix A: Equations of the Model 40

Appendix B: Variable Names and Definitions 46

$\begin{array}{ll}\text { References } & 53\end{array}$ 


\section{Introduction}

Like other developing regions in the post-World War II era, the demographic transition in the Middle East and North Africa (MENA) region has given rise to rapid labor force growth. But with an average growth rate above 3 percent since the 1960s, no other region comes close to the magnitude and persistence of MENA's labor market pressures. And while employment growth was relatively strong in the 1970s, it failed to keep pace with the expansion of the labor force during the 1980s and 1990s. As a result, MENA recorded some of the highest unemployment rates among developing regions in the 1990s. Recent estimates indicate that unemployment rates range from about 2.3 percent in the United Arab Emirates to close to 29.8 percent in Algeria (see World Bank (2004)). For the region as a whole, the unemployment rate is currently estimated at 15 percent of the labor force. ${ }^{1}$ Based on current trends in job creation, the prospects for absorbing new entrants into labor markets and those currently unemployed are rather bleak. With the labor force growing in the present decade at 3.4 percent per annum, the average unemployment rate for the region could reach 22 percent by 2010 .

Low output growth is often the "proximate" cause for the rise in unemployment. Following the oil bust in the late 1980s, the region experienced a weak recovery in the 1990s due to the protracted pace of policy reforms. But there are also structural reasons for unemployment that were not addressed by policymakers in the past decade. MENA countries exhibit rigidities in educational systems, wage setting, and regulatory regimes due to the dominance of the public sector in labor markets. Although rates of human capital accumulation have remained steady, MENA has reaped less than its potential in terms of economic growth and job creation. Government legislation on hiring and firing, minimum wages, and on collective bargaining agreements as well as employment guarantees in the public sector have interfered with the efficient functioning of the labor market. ${ }^{2}$ In normal times, the impact of

\footnotetext{
${ }^{1}$ Youth unemployment ranges from 37 percent of total unemployment in Morocco to 73 percent in Syria, with a simple average of 53 percent for all countries for which data are available. Except in Jordan and Lebanon, first-time job seekers make up more than 50 percent of the unemployed (ILO 2003).

${ }^{2}$ See for instance Pissarides (1993) and Pritchett (1999). In countries where wage levels fell in real terms during the 1990s, educated and experienced workers were affected the most, leading to a degradation of skills. Despite this, recent estimates suggest that returns to education are generally higher in the public sector than in the private sector at nearly all education levels but the university level (Assaad (2002) and World Bank (2004)).
} 
some of these structural rigidities may well be mitigated by the existence of large informal sectors. However, in periods of significant structural changes, they could turn into binding constraints on the expansion of output and employment. In such conditions, reforming the labor market becomes an important element of any reform program aimed at stimulating growth and promoting job creation.

Accordingly, the purpose of this paper is to offer a quantitative analysis of the impact of labor market reforms on growth, real wages, and unemployment in labor-exporting MENA countries. ${ }^{3}$ We begin in Section 2 with a brief overview of the main features of the labor market in five laborexporting MENA countries, namely, Algeria, Egypt, Jordan, Morocco, and Tunisia. ${ }^{4}$ Section 3 presents a quantitative framework that captures many of these features (such as a large informal urban sector, active trade unions, public sector employment, and international labor flows), as well as other important structural features of these countries, such as an unfunded pension system. ${ }^{5}$ Section 4 discusses the calibration procedure and parameter values. Section V presents simulation experiments focusing on four types of individual policy shocks: a reduction in payroll taxation on unskilled labor, reductions in public sector wages and the size of the government workforce, higher employment subsidies to the private sector, and a reduction in the bargaining power of trade unions.

We also consider a "composite" reform package, involving a cut in payroll taxes and public sector employment, as well as a reduction in unions' bargaining strength. The extent to which high payroll taxes have tended to discourage the demand for (unskilled) labor has been an important policy issue in MENA countries in general. Our framework allows us to consider the implications of both revenue- and budget-neutral changes in these taxes, and the various channels through which they affect job creation and unem-

\footnotetext{
${ }^{3}$ Our focus on LE-MENA countries only is due to the fact that the characteristics of the labor market in these countries (as well as other structural economic features) differ significantly from those of the labor-importing countries of the region.

${ }^{4}$ Yemen is also an important labor-exporting country in MENA, but due to the lack of reliable information on the labor market in that country we chose to exclude it from our review.

${ }^{5}$ In principle, a rigorous analysis of pension systems and pension reform would require the use of an intergenerational framework, such as the OLG-CGE model discussed by Farmer and Wendner (1999), or more recently by Beetsma, Bettendorf, and Broer (2003), Cavalletti and Lubke (2002) and Fehr, Hans, and Erling Ateigum (2002). Our analysis should be viewed as an approximation only.
} 
ployment. The concluding section summarizes the results and draws together the main policy lessons of the analysis. It emphasizes the need for an overall package of reforms, involving not only labor market policies but also other structural measures, to foster sustained growth in output and employment in labor-exporting MENA countries.

\section{Some Basic Facts}

The functioning of the labor market in MENA countries in general, and laborexporting countries in particular, has been reviewed in a number of recent contributions. ${ }^{6}$ Here we briefly review some of the salient features of this market (as summarized in Figure 1), in order to motivate the specification of the model developed in the next section.

Fundamentally, the labor market in labor-exporting MENA countries can be characterized as consisting of three segments: the rural sector, which continues to employ a sizable proportion of the labor force in many countries; the informal urban sector, characterized mostly by self-employment and a limited proportion of hired labor, a high degree of wage flexibility, low employment security, and no enforcement of labor regulations; and the formal (public and private) urban sector, where workers are hired on the basis of explicit contracts and the degree of compliance with labor regulation (particularly in the public sector) is relatively high.

The informal sector accounts for a large fraction of the labor force. Estimates of informal employment range from a low of 42 percent of nonagricultural employment in Syria to a high of 55 percent in Egypt. Although moderate compared to other developing regions, these estimates are high given the large share of public sector employment. In most labor-exporting MENA countries, the public sector is the dominant employer in the formal sector (see Abrahart, Kaur, and Tzannatos (2002)). When measured as a percentage of nonagricultural employment, the public sector is the highest among developing regions. Governments are often considered as "employers of first resort" especially for people with middle and higher education levels. The perpetuation of employment guarantees in government hiring, and

\footnotetext{
${ }^{6}$ See Shaban et al. (2001) and World Bank (2004)). A more detailed discussion of the features of the labor market in MENA countries is provided by Hollister and Goldstein (1994) and Salehi-Esfahani (2001). See also Agénor (1996, 2004) for a more general discussion of the features of labor markets in developing countries.
} 
mismatched wage expectations resulting from generous public sector compensation and benefits policies, have contributed to the continued preference for public sector jobs.

Although open unemployment has increased in recent years, underemployment remains pervasive. ${ }^{7}$ Open and disguised unemployment (which affects disproportionately the young and women) amount to anywhere between 25 and 60 percent of the labor force in some countries. A large majority of the openly unemployed has secondary or post-secondary degrees but open unemployment is also becoming more widespread among unskilled workers. Part of this unemployment is "queueing" or "wait" unemployment, resulting from public sector hiring and wage-setting practices, as shown for instance by Assaad (1997) in the case of Egypt. The unemployed are essentially those who would have had a chance at a formal job in the public sector in the past and continue to have expectations of acquiring such a job. Those with no education must either accept whatever employment is available to them, no matter how casual, or create their own job in order to survive.

Labor market regulations, including restrictions on hiring and firing, as well as minimum wage legislation, are widespread in the region. In all laborexporting MENA countries (except Jordan) there is a minimum wage regulation, although its impact on wage formation is not always clear. ${ }^{8}$ In Egypt and Tunisia, compliance with minimum wages is mostly limited to the public sector. In recent years, high unemployment in Morocco has led authorities to allow the private sector to hire workers at wages below the minimum rate. Restrictions on layoffs in the formal sector (and often generous severance payments) make firing redundant workers difficult in most labor-exporting MENA countries. In practice, however, the enforcement of the law is weak; compliance with existing regulations is limited to the formal sector. Thus, although labor market regulations may be pervasive on paper, their impact is mitigated by weak enforcement and the existence of large informal sectors.

Wage determination often departs from market-clearing mechanisms as

\footnotetext{
${ }^{7}$ Published measures of unemployment mostly include unemployed workers looking for jobs in the formal sector, but not underemployed workers in the informal and rural sectors, that is, disguised unemployment. For the difficulty of measuring unemployment in MENA countries, see for instance Rama (1998) for Tunisia.

${ }^{8}$ Said (2001) found no close correlation between minimum wages and unskilled wages in Morocco; and during the 1980s, real wages for these workers fell faster than the real legal minimum wage. However, other evidence, reviewed by Agénor and El Aynaoui (2003), suggests the minimum wage is binding in urban areas.
} 
a result of legal restrictions, the existence of labor unions, and imperfectly competitive wage-setting behavior by firms. Wages in agriculture and the urban informal sectors tend to be highly flexible. In contrast, some urban formal sectors show rigid systems that are characterized by segmentation and binding institutional constraints. ${ }^{9}$ In most countries, civil service pay remains a point of reference for public enterprises and many large firms in the formal private sector. This "leadership effect" of public wage settlements is a source of downward rigidity in wage behavior in the private sector. Among non-wage labor costs, social security contributions (which are typically shared between employers and employees) are particularly significant. In Algeria, contributions to the social security system alone constitute more than 36 percent of total labor costs.

With the exception of Jordan, where collective bargaining is practically non-existent, labor unions in Algeria, Egypt, Morocco, and Tunisia play a significant role in collective bargaining at the national level (see for instance Assaad and Commander (1994) for Egypt). This occurs despite the fact that actual unionization rates are relatively low in most of these countries (except Egypt) and union membership tends to be primarily in the public sector. The trade union movement is usually highly centralized, except in Morocco; its influence on wage formation is often through the political process (by lobbying to secure increases in minimum wages, for instance) rather than through industrial action, such as strikes and other forms of work disruptions. Through their influence on political parties, unionized workers are also able to exert considerable pressure to maintain job security.

Finally, international migration flows are an important source of foreign exchange and income for all of these countries. In the 1970s and 1980s, the peak years of oil-led growth in the region, the Gulf countries experienced unprecedented labor force growth driven primarily by the large number of immigrants seeking work from the labor-exporting MENA economies, especially Egypt and Jordan. During the same period, millions of migrants

\footnotetext{
${ }^{9}$ Labor market segmentation refers to a situation where observationally identical workers (that is, workers with similar qualifications) receive different wages depending on their sector of employment. It is a pervasive feature of LE-MENA countries. Segmentation may be induced by various factors: government intervention in the form of minimum wages; trade unions, which may prevent wages from being equalized across sectors by imposing a premium for their members; and efficiency wages, resulting from nutritional factors, turnover costs or productivity considerations (see Agénor $(1996,2004)$ ). The first two sources of segmentation are incorporated in the model presented in the next section.
} 
from Morocco, Tunisia, and (to a lesser extent) Algeria sought work in Europe. The 1990s witnessed a sharp fall in the outflows of workers from the sending countries in the region even though remittances remained an important source of income (see Figure 1). These flows play a significant role in the adjustment of the domestic labor market, in ways that we discuss more specifically below.

\section{A Formal Framework}

We now describe a quantitative framework to analyze the impact of labor market reforms in labor-exporting MENA countries. ${ }^{10}$ The model captures many of the structural features of the labor market highlighted in the foregoing discussion. In this section, we briefly summarize the main features of the model (focusing on the production structure, the labor market, and the pension system), with a complete list of equations provided in Appendix A, and variable definitions in Appendix B.

\subsection{Production}

The composition of output and the structure of the labor market are summarized in Figure 2. The basic distinction on the production side is that between rural and urban sectors. The rural sector (or agriculture) produces only one good, which is sold both on domestic markets and abroad. Urban production includes both formal and informal components; in addition, the formal urban economy is separated between production of a private good and a public good. Land available for production in agriculture is in fixed supply. Gross output in the rural sector, as well as in all other sectors, is given by the sum of value added and intermediate consumption (equation (A1)). Value added is assumed to be produced with a Cobb-Douglas function of a composite factor defined as a function that depends on the number of unskilled rural workers employed in agriculture and the economy-wide stock of public physical capital (equation (A2)). The presence of public physical capital in the production function of the agricultural good is based on the view that a

\footnotetext{
${ }^{10}$ The model is based on the Integrated Macroeconomic Model for Poverty Analysis (IMMPA) framework developed by Agénor (2003), Agénor, Izquierdo and Fofack (2003), and Agénor, Fernandes, and Haddad (2003), modified to account for international labor migration (as in Agénor and El Aynaoui (2003)) and a social security system.
} 
greater availability of public physical capital in the economy (roads, storage facilities, power grid, and the like) improves the productivity of large-scale producers and other production units in agriculture, because it facilitates not only trade and domestic commerce but also the production process itself. For simplicity, the area of land allocated to production is normalized to unity. Agricultural production exhibits decreasing returns to scale in the remaining (composite) input.

Value added in the informal economy is given as a function of the number of unskilled workers employed there, with decreasing returns to scale (equation (A4)). Value added in the public sector is generated by combining skilled and unskilled labor using a CES function (equation (A5)). Employment levels of both categories of workers are treated as exogenous.

Private formal production uses as inputs skilled and unskilled labor, as well as physical capital. Skilled labor and private physical capital have a higher degree of complementarity (lower degree of substitution) than physical capital and unskilled workers. In order to account explicitly for these differences in the degree of substitutability among inputs, we adopt a nested production structure. At the lowest level, skilled labor and private capital are combined to form a composite input with a low elasticity of substitution between them (equation (A8)). At the second level, this composite input is used together with unskilled labor to form a second composite input (equation (A7)). The elasticity of substitution between the first composite input and unskilled workers is taken to be higher than between skilled employment and private capital. The final layer combines the second composite input and the stock of government capital as production inputs (equation (A6)).

\subsection{The Labor Market}

Unskilled workers in the economy may be employed either in the rural economy, $U_{R}$, or in the urban economy, $U_{U}$, whereas skilled workers are employed only in the urban formal sector.

Agriculture and Internal Migration The demand for labor in the agricultural sector, $U_{A}^{d}$, can be derived from profit maximization as

$$
U_{A}^{d}=\left(V_{A}^{1+\frac{\rho_{X A}}{1-\eta_{X A}}} \frac{1-\eta_{X A}}{w_{A}} \cdot \frac{\beta_{X A}}{\alpha_{X A}^{\rho_{X A}}}\right)^{\frac{1}{1+\rho_{X A}}}, \quad \text { where } w_{A}=\frac{W_{A}}{P V_{A}},
$$


where $V_{A}$ is value-added in the agricultural sector, $W_{A}$ denotes the nominal wage, and $P V_{A}$ is the value added price (net of input costs) in the agricultural sector.

Nominal wages in agriculture adjust to clear the labor market. Let $U_{R}^{s}$ denote labor supply in the rural sector; the equilibrium condition is thus given by

$$
U_{R}^{s}=U_{A}^{d}\left(V_{A}, \frac{W_{A}}{P V_{A}}\right) .
$$

Over time, $U_{R}^{s}$ grows at the exogenous population growth rate, $g_{R}$, net of worker migration to urban areas, $M I G$ :

$$
U_{R}=U_{R,-1}\left(1+g_{R}\right)-M I G
$$

In the spirit of Harris and Todaro (1970), the incentives to migrate are taken to depend negatively on the ratio of the average expected consumption wage in rural areas to that prevailing in urban areas. Unskilled migrant workers may be employed either in the private formal sector, in which case they are paid a minimum wage, $W_{M}$, or they can enter the informal economy and receive the market-determined wage in that sector, $W_{I}$. When rural workers make the decision to migrate to urban areas, they are uncertain as to which type of job they will be able to get, and therefore weigh wages in each sector by the probability of finding a job in that sector. These probabilities are approximated by prevailing employment ratios. Finally, migrants consider what their expected purchasing power in rural and urban areas will be, depending on whether they stay in the rural sector and consume the "typical" basket of goods of rural households, or migrate and consume the "typical" urban basket of goods.

The expected, unskilled urban real wage, $E w_{U}$, is thus a weighted average of the minimum wage in the formal sector and the going wage in the informal sector, deflated by the urban consumption price index, $P_{U R B}$ :

$$
E w_{U}=\frac{\theta_{U} W_{M,-1}+\left(1-\theta_{U}\right) W_{I,-1}}{P_{U R B,-1}},
$$

where $\theta_{U}$ is the probability of finding a job in the urban formal sector, measured by the proportion of unskilled workers in the private formal sector, relative to the total number of unskilled urban workers looking for a job 
in the urban formal sector, $U_{F}^{s}$, net of government employment, $U_{G}$, in the previous period: ${ }^{11}$

$$
\theta_{U}=\frac{U_{P,-1}}{U_{F,-1}^{s}-U_{G,-1}} .
$$

In the rural sector, the employment probability is equal to unity, because workers can always find a job at the going wage. Assuming a one-period lag, the expected rural consumption real wage, $E w_{A}$, is thus

$$
E w_{A}=\frac{W_{A,-1}}{P_{R,-1}}
$$

where $P_{R}$ is the rural consumption price index.

The migration function can therefore be specified as

$$
M I G=U_{R,-1} \lambda_{m}\left[\sigma_{M} \ln \left(\frac{E w_{U}}{E w_{A}}\right)\right]+\left(1-\lambda_{m}\right) \frac{U_{R,-1}}{U_{R,-2}} M I G_{-1},
$$

where $0<\lambda_{m}<1$ measures the speed of adjustment and $\sigma_{M}>0$ the elasticity of migration flows with respect to expected wages. This specification assumes that costs associated with migration or other frictions may delay the migration process, introducing persistence in migration flows.

The Urban Sector The public sector employs an exogenous number of unskilled workers, $U_{G}$, at the nominal wage rate $W_{U G}$, whereas the demand for unskilled labor by the formal private sector is determined by firms' profit maximization subject to the given minimum wage, $W_{M}$. Both wages are assumed to be fully indexed on the urban formal price index, $P_{F}$ :

$$
W_{U G}=\omega_{U G} P_{F}, \quad W_{M}=\omega_{M} P_{F},
$$

where $\omega_{M}$ and $\omega_{U G}$ measure exogenous real wages.

Labor demand by the formal private sector is determined by firms' profit maximization. We assume also that firms pay a payroll tax, at the rate $0<\operatorname{ptax}_{U}<1$ on unskilled labor. This tax is proportional to the wage bill, $W_{M} U_{P}$. Firms also receive a nominal employment subsidy on unskilled labor

\footnotetext{
${ }^{11}$ Note that the specification of $\theta_{U}$ assumes complete job turnover outside the government sector every period.
} 
of $E S_{U}<W_{M}$ per worker. Unskilled labor demand by the private sector is thus given by

$$
U_{P}^{d}=T_{1}\left(\frac{P T_{1}}{\left(1+p t a x_{U}\right) W_{M}-E S_{U}} \frac{\beta_{X P 1}}{\alpha_{X P 1}^{\rho_{X P 1}}}\right)^{\sigma_{X P 1}},
$$

where $\sigma_{X P 1}=1 /\left(1+\rho_{X P 1}\right)$ measures the elasticity of substitution between unskilled labor and the composite input.

We assume, as in Agénor (2002), that mobility of the unskilled labor force between the formal and informal sectors is imperfect as a result of relocation and congestion costs. Migration flows are determined by expected income opportunities, again in line with Harris and Todaro (1970). Specifically, the supply of unskilled workers in the formal sector (including public sector workers), $U_{F}^{s}$, is assumed to change over time as a function of the expected wage differential across sectors, measured in real terms. Wage and employment prospects are formed on the basis of prevailing conditions in the labor market. Because there is no job turnover in the public sector (as noted earlier), the expected nominal wage in the formal economy is equal to the minimum wage weighted by the probability of being hired in the private sector. Assuming that hiring in that sector is random, this probability can be approximated by the ratio between employed workers and those seeking employment during the previous period, $U_{P,-1}^{d} /\left(U_{F,-1}^{s}-U_{G,-1}\right)$. The expected nominal wage in the informal economy, $W_{I}$, is simply the going wage, because there are no barriers to entry in that sector. Assuming a one-period lag, the supply of unskilled workers in the formal sector thus evolves over time according to

$$
\frac{U_{F}^{s}}{U_{F,-1}^{s}}=\left\{\frac{U_{P,-1}^{d}}{U_{F,-1}^{s}-U_{G,-1}}\left(\frac{W_{M,-1}}{W_{I,-1}}\right)\right\}^{\beta_{F}}, \quad \beta_{F}>0
$$

where $\beta_{F}$ is the elasticity of formal sector labor supply growth with respect to expected wages. The rate of unskilled unemployment in the formal sector, $U N E M P_{U}$, is thus given by

$$
U N E M P_{U}=1-\frac{\left(U_{G}+U_{P}^{d}\right)}{U_{F}^{s}} .
$$

From (A4), the demand for labor in the informal sector can be derived as

$$
U_{I}^{d}=\beta_{X I}\left(V_{I} / w_{I}\right)
$$


where $V_{I}$ is value added in the informal sector and $w_{I}$ the product wage, given by $w_{I}=W_{I} / P V_{I}$, with $P V_{I}$ denoting the price of value added in the informal sector.

The supply of labor in the informal economy, $U_{I}^{s}$, is obtained by subtracting the unskilled labor supply in the formal sector, $U_{F}^{s}$, from the urban unskilled labor force, $U_{U}$ :

$$
U_{I}^{s}=U_{U}-U_{F}^{s} .
$$

The informal labor market clears continuously, so that $U_{I}^{d}=U_{I}^{s}$. From equations (11) and (12), the equilibrium nominal wage is thus given by

$$
W_{I}=\beta_{X I}\left(\frac{P V_{I} V_{I}}{U_{I}^{s}}\right) .
$$

The urban unskilled labor supply, $U_{U}$, grows as a result of "natural" urban population growth and migration of unskilled labor from the rural economy, as discussed earlier. In addition, a quantity $S K L$ of urban unskilled workers acquires skills and leaves the unskilled labor force to augment the supply of skilled workers in the economy. We make the additional assumption that individuals are born unskilled, and therefore natural urban population growth (not resulting from migration or skills acquisition factors) is represented by urban unskilled population growth only, at the exogenous (gross) rate $g_{U}$. Finally, there are international migrations, the flow of which is measured by $I M I G$, and retirement from the urban labor force, measured by $\delta_{N P}^{U} U_{U}$, which is defined below. Thus, the urban unskilled labor supply evolves according to

$$
U_{U}=\left(1+g_{U}-\delta_{N P}^{U}\right) U_{U,-1}+M I G-S K L-I M I G,
$$

where $\delta_{N P}^{U} \leq 1+g_{U}$.

As noted earlier, the employment levels of both skilled and unskilled workers in the public sector are taken as exogenous. Given that some workers retire in every period, we have

$$
U_{G}=\left(1+g_{U G}-\delta_{N P}^{U}\right) U_{G,-1},
$$

where $g_{U G}>0$ is the exogenous growth rate of the unskilled labor force in the public sector.

The nominal wage that skilled workers in the public sector earn, $W_{S G}$, is also indexed on the urban formal consumption price index: 


$$
W_{S G}=\omega_{S G} P_{F},
$$

where $\omega_{S G}$ is an exogenous real wage.

To determine wages and employment for skilled labor in the private formal sector, we use the "right to manage" approach, in which firms bargain with trade unions over the nominal wage, $W_{S}$, and set unilaterally the level of employment. In addition, we assume that private urban firms pay a payroll tax on the skilled labor wage bill, at the rate $0<\operatorname{ptax}_{S}<1$, and receive a nominal employment subsidy of $E S_{S}<W_{S}$ per skilled worker. The demand for skilled labor, $S_{P}^{d}$, is therefore given by

$$
S_{P}^{d}=T_{2} \kappa_{S}\left(\frac{P T_{2}}{\left(1+p \operatorname{tax}_{S}\right) W_{S}-E S_{S}} \cdot \frac{\beta_{X P 2}}{\alpha_{X P 2}^{\rho_{X} 2}}\right)^{\sigma_{X P 2}},
$$

Following Booth (1995, pp. 124-26) and Layard, Nickell, and Jackman (1991, pp. 100-3), $W_{S}$ is determined as follows. Assume that all private sector firms are unionized, or equivalently that all workers belong to a single (representative) union. Let $\Omega_{S}$ denote the union's reservation wage and $P R O F_{P}$ firms' profits. Under the Nash bargaining approach, the bargained wage must solve, subject to (16),

$$
\max _{W_{S}} N_{S}=\left[S_{P}^{d}\left(W_{S}-\Omega_{S}\right)\right]^{\nu} P R O F_{P},
$$

where $\nu$ is a measure of the trade union's bargaining power. The bargained wage must therefore satisfy the first-order condition

$$
\frac{\partial \ln N_{S}}{\partial W_{S}}=\frac{\nu \partial S_{P}^{d}}{S_{P}^{d} \partial W_{S}}+\frac{\nu}{W_{S}-\Omega_{S}}-\frac{S_{P}^{d}}{P R O F_{P}}=0,
$$

because $\partial P R O F_{P} / \partial W_{S}=-S_{P}^{d}$ by the envelope theorem (each firm will choose employment ex post such that $W_{S}$ is equal to the marginal value product of skilled labor). This yields

$$
\frac{\nu W_{S}}{W_{S}-\Omega_{S}}=\nu \varepsilon_{S_{P}^{d} / W_{S}}+\frac{W_{S} S_{P}^{d}}{P R O F_{P}},
$$

where $\varepsilon_{S_{P}^{d} / W_{S}}=-\left(\partial S_{P}^{d} / \partial W_{S}\right)\left(W_{S} / S_{P}^{d}\right)$ is the wage elasticity of the demand for skilled labor. The term on the left-hand side of this expression measures the proportional marginal benefit to the bargain from the proportional increase in the skilled wage. The benefit associated with a wage increase incurs 
only to the union, so it is weighted by the union's bargaining power, $\nu$. The first term on the right-hand side is the union's proportional marginal cost (the percentage reduction in employment due to the proportional increase in the wage) weighted by the union's bargaining power. The second term on the right-hand side represents the firm's proportional marginal cost. Condition (18) indicates therefore that the bargained wage is set such that the proportional marginal benefits to both parties from a unit increase in wages is exactly equal to the proportional marginal cost to each party.

The union's reservation wage, $\Omega_{S}$, is assumed to be related positively to skilled wages in the public sector, $W_{S G}$, and negatively to the skilled unemployment rate, $U N E M P_{S}$. Wage setting in the public sector is assumed to play a signaling role to wage setters in the rest of the economy. When unemployment is high, the probability of finding a job (at any given wage) is low. Consequently, the higher the unemployment rate, the greater the incentive for the union to moderate its wage demands and boost employment. The above expression can thus be rewritten as

$$
\frac{W_{S}}{W_{S}-\Omega_{0} U N E M P_{S}^{-\phi_{1}} W_{S G}^{\phi_{2}}}-\varepsilon_{S_{P}^{d} / W_{S}}-\frac{W_{S} S_{P}^{d}}{\nu P R O F_{P}}=0,
$$

where $\Omega_{0}, \phi_{1}, \phi_{2}>0$, and $U N E M P_{S}$ is defined below. Using the implicit function theorem, it can be established that lower unemployment, higher public sector wages, or an increase in the bargaining strength of the union, raise the level of wages in the private sector.

Given that firms are on their labor demand curve, open skilled unemployment may emerge. The rate of skilled unemployment, denoted $U N E M P_{S}$, is given by the ratio of skilled workers who are not employed either by the private or the public sector, divided by the total (urban) population of skilled workers:

$$
U N E M P_{S}=\frac{S-S_{G}^{T}-S_{P}^{d}}{S},
$$

where $S_{G}^{T}$ is the total number of skilled workers in the public sector, engaged in both the production of public services, $S_{G}$, and education, $S_{G}^{E}$ (see below):

$$
S_{G}^{T}=S_{G}+S_{G}^{E}
$$

$S_{G}^{T}$ grows over time according to

$$
S_{G}^{T}=\left(1+g_{S G}-\delta_{N P}^{S}\right) S_{G,-1}^{T},
$$


where $g_{S G}>0$ is the exogenous growth rate of the skilled labor force in the public sector.

We assume that skilled workers who are unable to find a job in the formal economy opt to remain openly unemployed, instead of entering the informal sector (in contrast to unskilled workers), perhaps because of adverse signaling effects, as discussed by Agénor (2003).

The evolution of the skilled labor force depends on the rate at which unskilled workers acquire skills:

$$
S=\left(1-\delta_{S}-\delta_{N P}^{S}\right) S_{-1}+S K L
$$

where $0<\delta_{S}<1$ is the rate of "depreciation" or "de-skilling" of the skilled labor force.

Skills Acquisition The acquisition of skills by unskilled workers takes place through a free education system operated by the public sector. Specifically, the flow of unskilled workers who become skilled, $S K L$, is taken to be a CES function of the "effective" number of teachers in the public sector, $S_{G}^{E}$, and the government stock of capital in education, $K_{E}$ :

$$
S K L=\left[\beta_{E}\left(\varphi S_{G}^{E}\right)^{-\rho_{E}}+\left(1-\beta_{E}\right) K_{E}^{-\rho_{E}}\right]^{-\frac{1}{\rho_{E}}},
$$

where $\varphi$ measures the productivity of public workers engaged in providing education. $\varphi$ is assumed to depend on the relative wage of skilled workers in the public sector, $W_{S G}$, relative to the expected wage for that same category of labor in the private sector, which (in the absence of unemployment benefits) is given by one minus the unemployment rate, $1-U N E M P_{S}$, times the going wage, $W_{S}$. Using the effort function derived by Agénor and Aizenman (1999) yields:

$$
\varphi=1-\varphi_{m}\left[\frac{\left(1-U N E M P_{S,-1}\right) W_{S,-1}}{W_{S G,-1}}\right]^{\delta_{E}}, \quad \delta_{E}>0,
$$

where $0<\varphi_{m}<1$ denotes the "minimum" level of effort. ${ }^{12}$

\footnotetext{
${ }^{12}$ Note that we do not explain endogenously the allocation of unskilled workers' time between production and learning - an important trade-off from the individual's point of view. Allocating more time to learning reduces the individual's current labor income, but enhances his (or her) human capital, thereby increasing its earnings in the future. To the extent that public capital in education enters as an input to the human capital production
} 
International Labor Migration As noted earlier, international migration is an important feature of the labor market in labor-exporting MENA countries. We assume here that migration involves only unskilled workers, and that potential migrants are in the urban sector (as captured in (14)). Moreover, international migration flows are taken to be determined by two factors: the expected urban real wage for unskilled labor, $E w_{U}$, given by (4), relative to the expected foreign wage measured in terms of the urban formal price index, $E w_{F O R}$, defined as

$$
E w_{F O R}=\frac{E R \cdot W_{F O R,-1}}{P_{F,-1}},
$$

with $W_{F O R}$ denoting the foreign wage measured in foreign-currency terms, assumed exogenous, and $E R$ is the exchange rate. Adopting a specification similar to (6), the migration function is specified as

$$
I M I G=U_{U,-1} \lambda_{i m}\left[\sigma_{I M} \ln \left(\frac{E w_{F O R}}{E w_{U}}\right)\right]+\left(1-\lambda_{i m}\right) \frac{U_{U,-1}}{U_{U,-2}} I M I G_{-1},
$$

where $0<\lambda_{i m}<1$ measures the speed of adjustment, and $\sigma_{I M}>0$ the elasticity of migration flows with respect to expected wages. Again, costs associated with migration (such as relocation costs) are assumed to introduce some degree of persistence. Remittances associated with international migration flows of unskilled labor are assumed to benefit unskilled households in the urban formal and informal sectors. ${ }^{13}$

\subsection{The Pay-as-you-go Pension System}

We assume that there is a pay-as-you-go pension system, whose current outlays to pensioners (retired workers in the urban formal sector, both public and private), denoted PENSIONS, are financed by payroll taxes on workers

function, as in (23), it would also affect private decisions to accumulate human capital. See for instance Glomm and Ravikumar (1998) for a formal model of the labor-learning choice, which emphasizes, however, flow spending on education.

${ }^{13}$ See Glystos $(2002,2003)$ for a discussion of the macroeconomic effects of foreign remittances in several MENA countries, including Egypt, Jordan, Morocco, and Tunisia. 
in the private formal sector and transfers from the government, TRSOC: ${ }^{14}$

$$
P E N S I O N S=\operatorname{ptax}_{U} U_{P}^{d}+\operatorname{ptax}_{S} S_{P}^{d}+T R S O C .
$$

Total pension outlays are given by the product of an average benefit, $B E N E F$, which is fully indexed (with a one-period lag) on the price index for the urban formal sector, $P_{F}$ :

$$
B E N E F=B E N E F_{-1}\left(1+\Delta \ln P_{F,-1}\right) .
$$

The number of pensioners at the current period, NUMPEN, consists of last period's "stock" (adjusted for a fixed mortality rate), plus the flow of skilled and unskilled workers retiring in each period, $N E W P E N$ :

$$
N U M P E N=\left(1-\delta_{N}\right) N U M P E N_{-1}+N E W P E N,
$$

where $\delta_{N}$ is the proportion of pensioners who die in each period. The number of new pensioners is defined as

$$
N E W P E N=\delta_{N P}^{U}\left(U_{P,-1}^{d}+U_{G,-1}\right)+\delta_{N P}^{S}\left(S_{P,-1}^{d}+S_{G,-1}^{T}\right) .
$$

This equation indicates that at the beginning of each period a fixed fraction $\delta_{N P}^{U}$ (respectively $\delta_{N P}^{S}$ ) of employed unskilled (respectively skilled) workers retire from the formal sector labor force.

Thus, total pension outlays are given by

$$
P E N S I O N S=B E N E F \cdot N U M P E N .
$$

If we assume that the pension fund cannot borrow directly from the public, and that its accounts must be balanced, government transfers are determined from (26), given (28):

$$
T R S O C=P E N S I O N S-\operatorname{ptax}_{U} U_{P}^{d}-\operatorname{ptax}_{S} S_{P}^{d}
$$

Alternatively, if government transfers are considered fixed, the budget constraint can be used to determine the pension benefit, $B E N E F$, after dropping (27):

$$
B E N E F=\frac{\operatorname{tax}_{U} U_{P}^{d}+p \operatorname{tax}_{S} S_{P}^{d}+T R S O C}{N U M P E N} .
$$

\footnotetext{
${ }^{14}$ Note that, in our model, only employers pay payroll taxes that serve to finance the pension system. In practice, workers also make significant contributions. However, we abstract from these contributions, given that the focus of our simulation experiments is on changes in payroll taxes paid by firms.
} 


\subsection{Other Model Features}

Components of supply and demand are described by equations (A37) to (A48). Both the informal and public sector goods are nontraded. Total supply in each sector is thus equal to gross production (equations (A39) and (A40)). Agricultural and private formal urban goods, by contrast, compete with imported goods. The supply of the composite good for each of these sectors consists of a combination of imports and domestically produced goods (equations (A38) and (A41)).

For the agricultural and informal sectors, aggregate demand consists of intermediate consumption and demand for final consumption (by both the government and the private sector), whereas aggregate demand for the public and private goods consists not only of intermediate consumption and final consumption but also of investment demand (equations (A42), (A43), (A44), and (A45)). Total demand for intermediate consumption of any good is the sum of intermediate consumption of this good over all production sectors (equation (A37)). Government expenditure on any good (except informal good) is equal to a fixed share of total government expenditure (equation (A47)). Household consumption of each good is the summation across all categories of households' consumption of this good (equation (A46)). Consumption by individual households is derived from a Linear Expenditures System (LES). Total private investment by private urban firms consists of purchases of both public and urban formal private goods and services (equation (A48)).

Regarding external trade, private firms in the urban formal sector allocate their output to exports or the domestic market according to a production possibility frontier/transformation function (equation (A9)). Allocation of agricultural output to domestic consumption and exports occurs according to a production possibility frontier (equation (A3)). Profit maximization requires firms to equate relative prices to the opportunity cost in production (equation (A49). Imports compete with domestic goods in the agricultural sector as well as in the private formal sector (equations (A38) and (A41)). Cost minimization requires the demand for imported vs. domestic agricultural and private urban goods to be a function of relative domestic and import prices (equation (A50)).

Prices are defined in equations (A51) to (A62). The value added price

of output is given by the gross price net of indirect taxes, less the cost of intermediate inputs (equation (A51)). The world prices of imported and 
exported goods are taken to be exogenously given. The domestic currency price of these goods is obtained by adjusting the world price by the exchange rate, with import prices also adjusted by the tariff rate (equations (A52) and (A53)). Because the transformation function between exports and domestic sales of the agricultural and urban private goods is linear homogeneous, the domestic sales prices are derived from the sum of export and domestic expenditure on agricultural and private goods divided by the quantity produced of these goods (equation (A54)). For the informal and public sectors, the composite price is equal to the domestic market price, which is in turn equal to the output price (equation (A56)). For the agricultural and private urban production sectors, the substitution function between imports and domestic goods is also linearly homogeneous, and the composite market price is determined accordingly by the expenditure identity (equation (A55)). The nested production function of private formal urban goods is also linearly homogeneous; prices of the composite inputs are derived in similar fashion (equations (A60) and (A61)). The price of capital is constructed by using the investment expenditure identity, which involves public and private-formal urban goods (equation (A62)). Finally, the consumption price indices for the rural, urban, and urban formal are given as weigted averages of composite good prices, with weights reflecting consumption patterns (equations (A57), (A58), and (A59)).

Profits and income are defined in (A63) to (A70). Firms' profits in the informal and agricultural sectors are defined as revenue minus total labor costs (equation (A63)). Profits of private-urban sector firms account for salaries paid to both skilled and unskilled workers (equation (A64)). Firms' income in the agricultural and the informal sector is equal to their profits (equation (A65)). But firms' income in the formal urban economy is equal to their profits minus corporate taxes and interest payments on foreign loans (equation (A66)). Household income is based on the return to labor (salaries), distributed profits, and transfers. Households are defined according to their sector of occupation. There are four categories of households: rural, urban informal, urban formal, and capitalists. The rural household comprises all rural workers; the urban informal household consists of workers in the urban informal sector; and the urban formal household consists of urban formal sector employees (skilled and unskilled). Finally, there is a capitalist-rentier household, whose income comes from firms' earnings in the formal private sector. Households in the rural and informal urban economy own the firms in which they are employed - an assumption that captures the fact that firms 
in these sectors tend to be small, family-owned enterprises. Income of rural households is equal to the sum of value added from production and transfers from the government (equation (A67)). Income of urban informal households also includes a fraction of foreign remittances from (unskilled) workers employed abroad (equation (A68)). Income of urban formal households depends on government transfers and salaries, foreign remittances, and pension payments (equation (A69)). Firms provide no source of income, because these groups do not own the production units in which they are employed. Firms in the private urban sector retain a portion of their after-tax earnings for investment financing purposes and transfer the remainder to capitalists. Thus, the capitalist-rentier household's income is the sum of transfer payments and distributed profits (equation (A70)).

Consumption, savings, and investment are described in equations (A71) to (A74). Each category of household saves a constant fraction of its disposable income, which is equal to total income minus income tax payments (equation (A71)). The portion of disposable income that is not saved is allocated to consumption (equation (A72)). The accumulation of capital over time depends on the flow level of investment and the depreciation rate of capital from the previous period (equation (A74)). The aggregate identity between savings and investment implies that total investment must be equal to total savings, which is itself equal to firms' after-tax retained earnings, total after-tax household savings, government savings, and foreign borrowing by firms and the government (equation (A73)). In the simulations reported later, this equation is solved residually for the level of private investment, which implies therefore that the model is "savings driven".

The government side is described in equations (A75) to (A80). Government expenditures consist of government consumption, which only has demand-side effects, and public investment, which has both demand- and supply-side effects. Public investment consists of investment in infrastructure, education, and health. We define investment in infrastructure as the expenditure affecting the accumulation of public infrastructure capital, which includes (as noted earlier) public assets such as roads, power plants and railroads. Investment in education affects the stock of public education capital, which consists of assets such as school buildings and other infrastructure determining skills acquisition, but does not represent human capital. In a similar fashion, investment in health adds to the stock of public assets such as hospitals, health clinics, and other government infrastructure affecting health. All value added in the production of public goods is distributed as 
wages. Thus, the current fiscal deficit is equal to tax revenue minus current household transfers, pension transfers, current expenditure on goods and services, wage expenditure, and interest payments on foreign public loans (equation (A75)). Net government saving is equal to minus the overall government budget deficit and is obtained by adding public investment expenditure to the current fiscal deficit (equation (A76)). Total tax revenues consist of revenue generated by import tariffs, sales taxes, income taxes (on both households and firms in the urban private sector), and payroll taxes net of employment subsidies (equation (A77)). Government investment is the sum of investment in infrastructure, investment in health, and investment in education, which are all considered exogenous policy variables (equation (A78)). Government investment increases the stock of public capital in either infrastructure, education or health. Accumulation of each type of capital is equal to the sum of the capital stock from the previous period and current-period investment minus depreciation of the capital stock from the previous period (equation (A79)). Because we assume that only the private urban good is used for capital accumulation, we deflate nominal investment by the demand price for private goods to obtain real investment. Infrastructure and health capital affect the production process in the private sector as they both combine to produce the stock of government capital (equation (A80)).

Finally, the balance of payments is defined in equations (A86) to (A88). The external constraint implies that any current account surplus (or deficit) must be compensated by a net flow of foreign capital, given by the sum of changes in foreign loans made to the government and to private firms (equation (A86)). The flow of remittances is equal to the foreign wage measured in foreign-currency terms times the stock of domestic workers abroad (equation (A87)). In turn, the stock of domestic workers abroad is the sum of new immigrants and the stock of domestic workers abroad from the previous period, minus attrition (equation (A88)).

\section{Calibration and Parameter Values}

This section presents a brief overview of the characteristics of the data underlying the model's social accounting matrix (SAM) and discusses the parameter values. 


\subsection{The Social Accounting Matrix}

The basic dataset consists of a SAM and a set of initial levels and lagged variables. The SAM encompasses 37 accounts including production and retail sectors ( 8 accounts), educational services ( 2 accounts), labor production factors and profits ( 5 accounts), enterprises ( 1 account), households (4 accounts), government current expenditures, taxes and pensions (12 accounts), government investment expenditures (3 accounts), private investment expenditures (1 account), and the rest of the world (1 account).

The SAM dataset was derived so as to (i) reflect characteristics of a typical labor-exporting MENA country, and (ii) represent an equilibrium dataset, including a balanced government budget, a zero balance of payments (BoP), and zero net foreign borrowing. Nevertheless, the net factor service account of the BoP includes private and foreign interest payments reflecting past foreign borrowing. The characteristics of the SAM data can be summarized as follows. On the output side, agriculture and the informal sector account for respectively 12 and 35 percent of total output at producer prices. In contrast, private urban formal production accounts for almost 46 percent of total output. On the demand side, private current expenditures account for 64 percent of GDP, whereas government current expenditures and wages account for 11 percent of GDP. At the same time, total investment expenditures represent 22 percent of GDP, implying that our "prototype" labor-exporting MENA country is running a trade surplus equivalent to 2.8 percent of GDP.

Looking at the BoP, total net remittances to households amount to 1.2 percent of GDP. Together with the trade balance surplus, this is financing a deficit on the net factor services account amounting to 4 percent of GDP. This includes private foreign interest payments (-1.5 percent of GDP) and government foreign interest payments ( -2.5 percent of GDP). The trade balance is dominated by non-agricultural imports and exports, with agricultural exports accounting for only 8 percent of total export earnings, and non-agricultural imports accounting for 92 percent of total import expenditures. The level of trade openness, measured by the ratio of the sum of imports and exports to GDP, amounts to a moderate 38 percent.

Looking at the government budget, indirect taxes in the form of production and retail level taxes (excluding payroll taxes) account for 84 percent of total government revenues. Household tax revenues, amounting to 13 percent of total government income, represents the largest revenue item among direct tax items, whereas enterprise taxes account for only 4 percent of revenues. 
On the expenditure side, domestic transfers and foreign interest payments account for respectively 24 and 9 percent of the budget, whereas consumption and savings for investment purposes amount to respectively 40 and 27 percent of the budget. Overall, the government relies heavily on indirect taxes for revenue collection (as is common in developing countries), while at at the same time allocating a significant fraction of its resources to investment.

\subsection{Behavioral Parameters}

Consider now the behavioral parameters of the model. In agriculture the Cobb-Douglas (share) parameter in the production of value added equals 0.8, whereas the CES substitution elasticity between rural labor and public capital equals $2 / 3$. Public capital is aggregated from infrastructure and health capital using a substitution elasticity of $1 / 2$. The informal sector only has one factor of production, unskilled labor, and the Cobb-Douglas (share) parameter equals also 0.8 . In contrast, the private formal sector has a threelevel nested production structure, with a bottom level substitution elasticity of $2 / 3$ between private capital and skilled labor, a middle level substitution elasticity of $7 / 6$ between the bottom level composite factor and unskilled labor, and a top level substitution elasticity of $5 / 6$ between the middle level composite factor and public capital. Finally, public sector value added is derived using CES aggregation of skilled and unskilled labor with a substitution elasticity of unity.

Turning to the factor market and the wage bargaining equation for private sector skilled wages, elasticities with respect to skilled labor unemployment and public sector wages are set respectively at -2.0 and 2.0 , whereas the wage elasticity of private skilled labor demand is -1.0. The parameter measuring the trade union's bargaining power is set at 0.7. Rural-urban and international migration elasticities with respect to relative expected wages are set respectively at 0.4 and 0.6 , whereas persistence parameters for rural-urban and international migration are set respectively at 0.1 and 0.3 . The formalinformal sector migration elasticity with respect to relative expected wages is 0.4 . the elasticity of substitution between publicly-employed teachers and public education capital in the skills-upgrading CES production function is $1 / 3$, whereas the elasticity of teachers effort with respect to relative wages is 0.8 .

The Armington elasticities for rural agricultural and urban formal sector goods imports are set respectively at $2 / 3$ and 1.5 . Similarly, the CET trans- 
formation elasticities for rural agricultural and urban formal sector goods exports are set respectively at $2 / 3$ and 1.5. Finally, household minimum consumption levels amount to 10 percent of initial consumption levels.

\section{Simulation Experiments}

In what follows we use the framework described above to analyze five types of labor market reforms: a reduction in payroll taxes on unskilled labor, assuming both neutral and non-neutral changes on the budget; reductions in public sector employment and wages; an active labor market policy consisting of higher employment subsidies to unskilled workers in the formal private sector; and a reduction in trade unions' bargaining strength. ${ }^{15}$ We also consider a composite reform package, which consists of a cut in payroll taxes and public sector employment, as well as a reduction in unions' bargaining power. In all of these experiments we use a savings-driven closure rule, and solve residually for private investment demand, using the aggregate savingsinvestment balance (equation (A73)). This allows us to study the "crowding in" and "crowding out" effects of labor market policies, through their impact on the government budget balance.

\subsection{Reduction in Payroll Taxes on Unskilled Labor}

The effects of a permanent, 5 percentage-point reduction in the payroll tax rate on unskilled labor are illustrated in Figure 3. In analyzing the impact of this policy measure on growth and employment, a key aspect involves evaluating its fiscal implications. For instance, assuming that the policy change must be neutral with respect to the budget deficit, what are the alternative options for offsetting the effect of a reduction in payroll taxation? To illustrate this type of interactions between labor market reforms and fiscal policy, we examine three alternative "closure" rules on the fiscal side. In the first, there is no offsetting change in revenue, and the government borrows domestically to balance its budget - implying therefore full crowding out of private investment, as implied by the aggregate savings-investment balance (equation (A73)). In the second, the policy is budget-neutral, and the government raises sales taxes on the private, formal sector good to offset the increase

\footnotetext{
${ }^{15}$ Results of all these experiements are summarized in Figures 3 to 9 . A set of Excel sheets, containing more detailed results, are available upon request.
} 
in additional expenditures on transfers to the pension system. In the third, the policy is also budget-neutral, and the government offsets the reduction in payroll taxes by an increase in income taxes on capitalists and rentiers. ${ }^{16}$ In all three cases, we assume that the accounts of the pension system are balanced through government transfers, as indicated in (29). Of course, even if the policy is budget-neutral in the sense described here, private capital formation may still be crowded out, as a result of general equilibrium effects leading to, say, smaller private savings relative to the baseline.

A number of results are common to all three payroll tax experiments. Reduced labor costs leads to increased employment of unskilled labor, as well as substitution away from skilled labor (and physical capital) in the private formal sector. A decrease in skilled labor wages - resulting from the rise in skilled unemployment, itself due to the reduction in the demand for that category of labor - partly offsets the initial tax-induced 5 percent increase in the differential between skilled and unskilled labor costs. The net increase in the labor cost differential amounts to around 3.8 percent in the longer term, implying a strong substitution away from skilled labor toward unskilled labor even in the long run.

The increase in unskilled employment is drawn partly from the pool of unemployed workers in the formal sector and partly from increasing migration from the informal sector. Increasing migration to the formal sector occurs against the backdrop of strongly increasing informal sector wages. The minimum wage increases over time as a result of full indexation on urban consumption prices, and higher demand for unskilled labor in the formal sector leads to a rise in the expected formal sector wage. Over time, the ensuing increase in the expected formal-informal sector wage differential leads to higher migration flows to the formal economy. This pushes the informal sector wage upwards. Employment in the informal sector also increases in the short run but tapers off in the medium to long term. The initial combination of reduced overseas and formal sector migration flows a year after the shock and beyond increases informal sector labor supply by $0.3-0.4$ percent. However, although reduced migration overseas, due to increased domestic urban wages, continues to add workers to the informal sector labor force, the subsequent reversal of formal sector migration coupled with migration outflows to the rural sector, leads to a gradual reversal of the initial increase in labor

\footnotetext{
${ }^{16}$ Of course, other offsetting changes, such as increases in direct tax rates on enterprises, or an increase in indirect taxes on urban goods, could also be considered.
} 
supply. The reduced supply of labor is matched by a reduction in demand due to the high informal sector wages. The mirror image of reduced informal sector employment is a gradual increase in rural employment. Accordingly, the cumulative effect of medium-term outward migration to rural areas, due to increasing agricultural wages, leads to a relatively strong expansion of labor supply in the rural sector.

At the aggregate level, the reduction in payroll taxes leads to a strong initial increase followed by a gradual decline in nominal GDP. In contrast, real GDP increases over time, indicating that the declining growth path for nominal GDP is a purely nominal phenomenon. The adjustment process involves a real exchange rate depreciation, which gradually raises exports and lowers imports in the long term. The increasing trade surplus is used to finance the net factor service income deficit, which rises due to declining migration overseas.

Whereas the growth paths of GDP and trade aggregates are relatively similar across payroll tax experiments, the growth paths of private consumption and investment are relatively sensitive - as could be expected - to whether or not there are offsetting changes in taxes. The growth paths of private consumption and investment are diverging strongly in the experiment with a non-neutral budget closure. The ensuing budget deficit is financed through domestic borrowing, leading to crowding out of private investment and higher disposable household income, which translates into increased private consumption.

The strong crowding-out effect disappears when sales or income taxes are raised to pay for increased transfers to the pension system. However, differences persist. Sales taxes on formal sector goods raise the price of investment goods and intermediate inputs, which depresses (everything else equal) profits, savings, and private capital accumulation. In contrast, an increase in the tax rate on capitalists' income reduces household disposable income and private consumption, but allows for increased investment in the long term. Thus, the scenario where reduced payroll tax revenues and increased transfers to the pension system are offset by increased household income taxes results in the highest long-term GDP growth rates. ${ }^{17}$ Growth in the formal

\footnotetext{
${ }^{17}$ Note that the model does not capture the disincentive effects of higher direct tax rates on labor supply (or participation rates). To the extent that these effects are large, the impact of higher output growth rates on unemployment would be ambiguous. The reason is that a reduction in labor supply (which would tend to lower unemployment) could be offset by large substitution effects toward physical capital.
} 
sector due to increased private capital accumulation is responsible for higher long-term aggregate growth in the latter scenario.

The impact on the government budget is of course related to the budget closure rule. Government transfers to the pension system will, in each case, increase by around 0.2 percent of GDP in the long run, due to the decline in own-financing, itself resulting from the reduction in payroll taxation. Without the introduction of alternative financing sources, this leads to a domestic borrowing requirement of 0.3 percent of GDP in the long term. In contrast, domestic borrowing is completely avoided in the long term, if budget-neutral specifications with variable sales and/or income taxes are applied. Looking at the pension system, total pension payments increases the most when higher government transfers are financed by increased sales taxes on formal sector goods. The number of workers who qualify to enter the pension system rises (due to the expansion of formal sector employment) by around 0.5 percent in the long run, regardless of the budget closure. However, whereas the average benefit rate decreases by 0.4 percent when increased government transfers are $a$ ) financed by higher income taxes, or $b$ ) not financed by tax increases, it only falls by 0.1 percent when higher formal sector sales taxes lead to increases in prices of formal sector goods.

\subsection{Cut in Public Sector Wages}

We now examine the effects of wage reductions for both unskilled public workers and skilled public employees (excluding teachers). Results of a permanent, 5 percent reduction in the wage rate for each labor category are summarized in Figures 4 and 5.

The reduction in public sector wages leads, in both cases, to a reduction in the public sector borrowing requirement and to crowding-in of private investment. A reduction in unskilled wages in the public sector, by contrast, has little impact on growth in the long term. The main channel through which public sector wage reductions is transmitted is a reduction in aggregate demand, induced by lower government consumption expenditures, and an increase in total domestic savings (due to a reduction in the budget deficit only, because private savings fall concomitantly with income), and thus private investment. With employment in the public sector fixed, the expansion in investment demand leads to increased private sector employment of unskilled labor and a reduction in the unemployment rate. In turn, the reduction in unemployment (which raises the probability of find- 
ing a job in the private formal economy) leads to strong migration into the formal sector. The increased employment and formal sector migration levels are, however, immediately reversed. The combination of declining demand for formal sector goods and increasing accumulation of capital lowers the demand for unskilled labor over time. Moreover, increasing informal sector wages and formal sector unemployment leads to outward migration from the formal sector. In the long term, employment levels are unchanged in every sector, and the higher level of production (in the formal sector) is entirely driven by increased private capital accumulation. Migration flows reverse themselves and unemployment rates remain unchanged at baserun levels. Looking at the pension system, overall pensions, including transfers from the government, remain unchanged. Accordingly, both the number of pensioners and the level of pension benefits are unchanged in the long term.

In contrast, a cut in skilled wages in the public sector has a relatively strong long-term impact on growth because of the leadership effect on private skilled wages. Reduced public sector wages spills over into lower private skilled wages and higher employment of that category of labor in the private sector. Combined with the cumulative effect of increased private investment, this leads to higher growth rates in the formal sector. At the same time, growth in the rural and urban informal sectors is driven by declining migration into the urban (formal) sector. The outward migration is driven by substitution of skilled for unskilled labor in private formal sector production, which leads to a declining formal-informal sector wage differential. In addition, an increase in the expected urban wage, due to increasing informal sector wages and a gradually declining unskilled unemployment rate, leads to a decline in international migration flows. The combination of declining international and formal sector migration leads to increasing labor supply in the urban informal sector, and, because of increasing rural wages, to further out-migration and higher labor supply in the rural sector.

Interestingly, a cut in public sector skilled wages leads to a long-term reduction in both skilled and unskilled formal sector unemployment rates. The reduction in unemployment among skilled workers results from increased formal sector employment. In contrast, the reduction in open unemployment among unskilled workers follows mainly from outward migration to the informal sector.

Looking at the current account, reduced international migration (resulting from the increase in the expected urban wage) leads to an increase in the net factor service account deficit. This is counterbalanced by an improvement 
in the trade balance, which comes about as a result of a small depreciation of the real exchange rate.

The pension system sees some minor changes in the long term, including a small increase in the number of retirees and a small decrease in the average pension benefit rate. The number of pensioners increases due to increased formal sector employment levels, while pension benefits decline because the strong supply response in the formal sector reduces formal sector prices. The overall effect is to leave overall pension payments, including government transfers to the pension system, unchanged in the long run. The main impact on the government budget is therefore to reduce the budget deficit through reduced consumption.

\subsection{Public Sector Layoffs}

The experiments of this section include public sector layoffs of both unskilled workers and skilled public employees (excluding teachers). Results of a permanent, 5 percent reduction in the number of workers in each labor category are summarized in Figures 6 and 7.

Reducing the size of public sector employment has the twin effects of increasing private capital accumulation and raising levels of employment in the private sector. Crowding-in of private investment is achieved because non-budget neutral layoffs turn into a smaller domestic government borrowing requirement. The increased private capital accumulation has a positive supply-side effect on formal sector output. Nevertheless, the net increase in relative demand for formal sector goods (resulting from higher private investment and lower private consumption), means that private formal sector employment levels also increases for both categories of workers.

Aggregate growth effects are absent in the case of unskilled labor layoffs. Real GDP declines in the short term, and returns to baserun levels in the longer run. Nevertheless, there is positive growth over time in every production sector other than public services, including the rural and urban informal sectors. Accordingly, while the aggregate growth impact is neutral in the long term due to lower value added in the public sector, the growth path has a distinct upward trend towards the end of the 10-year horizon. Positive formal sector growth is particularly evident throughout the simulation period. Short-term growth is due to increased employment of unskilled labor in the private sector, whereas long-term growth is mainly driven by higher private capital accumulation. In fact, employment of unskilled labor in the private 
sector falls over time and returns close to baserun levels in the long term. At the same time, growth in the rural agricultural and urban informal sectors are driven primarily by increased labor supplies, due to the cumulative impact of outward migration from the urban (formal) sector. Outward migration is particularly strong because declining employment prospects lowers the expected urban wage.

The unskilled unemployment rate increases sharply in the short term, because the rise in private sector employment is insufficient to absorb laidoff workers in the public sector. In the longer run, unskilled unemployment returns toward its baserun level, due to the cumulative effect of migration outflows into the urban informal and rural sectors. Accordingly, formal sector employment of unskilled labor is reduced to baserun levels, whereas the supply of unskilled labor in the formal sector declines by more than 1 percent in the long term. International migration flows increase in the short term but move in the opposite direction in the longer term due to higher domestic wages and lower unemployment levels.

In contrast to layoffs of unskilled government workers, layoffs of skilled public employees have markedly positive growth effects. Real GDP increases in both the short and the long term. Again, output growth occurs in all nonpublic sectors, but in contrast to the previous experiment involving unskilled labor layoffs, more balanced and stronger growth is recorded among the rural and urban informal and formal sectors. Strong formal sector growth is driven by increased employment of (skilled) labor in the short term. Thus, the short-term impact of skilled labor layoffs follows the pattern of unskilled layoffs. However, the long-term growth effect is driven by a combination of increased employment levels and private capital accumulation. Thus, the initial increase in the level of (skilled) labor employment persists in the long term, in contrast with the unskilled labor layoffs.

Growth in the rural and urban informal sectors is again driven by declining urban migration flows, resulting from layoffs of unskilled labor in the private sector. Sharply declining skilled labor wages (resulting from reduced union wage demands, due to increased unemployment among skilled workers) leads to increased substitution of skilled for unskilled labor in the private formal sector. The accompanying narrowing in wage differentials leads to declining urban (formal) migration and increasing rural and urban informal labor supplies. This leads to a decline in the open unskilled unemployment rate, and an accompanying increase in the expected urban formal sector wage, which partly reverses the strong initial reduction in migration from 
the formal sector. But high and increasing informal sector wages means that formal sector migration remain lower in the long term.

In line with the previous experiment involving layoffs of unskilled workers in the public sector, layoffs of skilled workers lead to higher unemployment for that category of labor while reducing unemployment among unskilled workers. Moreover, the reduction in unskilled unemployment is magnified in the longer run by the fall in the supply of unskilled labor in the formal sector induced by migration flows. This long-term reduction is, however, markedly smaller than in the case of unskilled layoffs. The increase in informal and formal urban wages, combined with the declining open unemployment rate, means that international migration flows decline as well in the long run. The cumulative effect on the domestic workforce abroad again leads to an increasing deficit in the net factor services account over time. This is made up for by a moderate improvement in the trade balance, which comes about through a small real exchange rate depreciation.

The main impact of public sector layoffs on the government budget is to reduce current consumption and domestic government borrowing requirements. In contrast, transfers to the pension system remain relatively unchanged. Overall, pension payments decline by around 0.2 percent in the long run. In the case of unskilled layoffs, the decline in pension payments are due solely to a decline in the number of retirees. Layoffs of unskilled workers result in the largest reduction in employment, and therefore result in the largest reduction in pensioners. In contrast, layoffs of skilled workers lead to lower pension payments partly because of declining numbers of retirees, and partly because of a declining average benefit rate. A stronger supply effect of skilled labor layoffs leads to declining formal sector prices and, accordingly, to an increasing pension benefit rate.

\subsection{Subsidies to Private Employment}

We now turn to an analysis of the impact of subsidies to employment of unskilled labor in the formal private sector under various government budget closures, including a) a non-neutral budget closure; b) a budget-neutral increase in sales taxes on private formal sector goods, and c) a budget-neutral increase in income taxes on capitalists. In each case, the increase in employment subsidy amounts to 5 percent of the base year private formal unskilled wage level. The simulation results are summarized in Figure 8.

The employment subsidy for unskilled labor increases the differential be- 
tween skilled and unskilled labor costs, in a manner similar to the 5 percent reduction in payroll taxes considered earlier. The only difference between the two sets of results comes from the fact that the payroll tax rate applies to the unskilled wage rate whereas the employment subsidy does not. The unskilled wage rate is fixed in real terms, but variations in consumer prices in the formal sector leads to some variation in its nominal value. However, these wage changes have minimal impact on the results, which are therefore almost identical to the results of the payroll tax experiments.

In particular, the reduction in unskilled labor costs leads to a strong increase in formal sector employment and a decline in open unskilled unemployment. The increase in unskilled employment is the main engine for formal sector growth. Initial migration flows also fuel increases in labor supply in the informal sector. However, subsequent outward migration from urban to rural areas leads to an increase in rural labor supply, and the initial increase in informal sector labor supply therefore tapers off. In the long term, aggregate growth is driven equally by rural and urban formal sector growth, when a non-neutral government budget closure is used. An increase in the public sector borrowing requirement leads to crowding-out of private investment, reduced capital accumulation, and depressed formal sector growth. In contrast, urban formal sector growth is markedly stronger than rural agricultural growth when employment subsidies are financed by higher income tax revenues. The domestic government borrowing requirement is eliminated and crowding-out of investment is reversed, leading to slightly increased capital accumulation in the long term. Unemployment among skilled workers increases slightly, regardless of the government budget closure. In contrast, strongly increasing labor demand in the private sector reduces the unskilled unemployment rate, in spite of a sharp long-term increase in labor supply. The deficit of the net factor services acount increases due to the cumulative effect of reduced international migration, but a compensating improvement in the trade balance means that the current account balance is left essentially unchanged. Finally, pensions payments increase marginally, due to a relatively strong increase in the number of retirees (itself resulting from a rise in formal sector employment) and a smaller decline in the pension benefit rate (due to declining formal sector prices). ${ }^{18}$

\footnotetext{
${ }^{18} \mathrm{~A}$ limitation of our analysis is that we do not account for the fact that employment subsidies may have unintended consequences, such as subsidized workers replacing unsubsidized ones, or employers firing subsidized workers once the subsidy period ends.
} 


\subsection{Reduction in Unions' Bargaining Strength}

We now turn our attention to a reduction in labor union bargaining strength. To do so we reduce the bargaining strength parameter, the coefficient $\nu$ in equation (17), from its initial level of 0.7 to a value of 0.6 . The results are shown in Figure 9.

The direct impact of the reduction in union bargaining power is to lower skilled wages and increase employment for skilled labor in the private sector. Increased production leads to lower formal sector goods prices and increased real demand for all goods, including agricultural and informal sector goods. The expansion of real private investment demand is particularly large. Increasing real demand, combined with a lower wage bill, raises firms' profits in the private formal sector. In turn, this boosts private savings and investment. The combination of higher skilled employment, and capital accumulation in the private sector, and increased unskilled employment in urban informal and rural sectors, leads to a rise in output, which persists in the long term. This growth scenario is therefore broad-based in the sense that it stems from both rural and urban formal sector growth, and to a lesser extent from urban informal sector growth.

The sharp drop in skilled wages leads to strong substitution away from unskilled labor in the urban formal sector. Although the large initial decline in private formal unskilled employment is partly reversed over time, it remains below its baseline value in the long term, as a result of the permanent nature of the reduction in the wage differential. Growth in the formal sector is thus driven by increased employment of skilled labor and private capital accumulation. The strong initial substitution away from unskilled labor also leads to high unemployment for that category of labor and a drop in expected urban wages. This leads to a marked initial decline in formal sector migration flows, and an equally large initial increase in labor supply in the informal sector. However, the strong migration response also reduces unemployment to below baserun levels. This increases the expected urban wage and, subsequently, leads to a reversal in the direction of formal sector migration flows. In the longer run, migration flows tend to increase labor supply in the urban informal sector at a constant rate and labor supply in the rural sector at an increasing rate. This leads to relatively fast long-term growth in the rural sector and slower but robust growth in the urban informal sector.

After an initial adjustment period, formal sector unemployment rates drop well below baserun levels and stay there in the long term. The reduc- 
tion in skilled unemployment follows from increased employment of skilled labor in the private sector. In contrast, the long-term reduction in unskilled unemployment follows from a reduction in the formal sector supply of unskilled labor, resulting itself from reduced migration flows.

The international wage differential drops in the long term, leading to a decline in overseas migration flows. This contrasts with the long-term decline in migration between rural and urban areas, where a high degree of persistence implies weak migration flows, in spite of a long-term increase in the wage differential.

The decline in international migration leads to an increase in the net factor services income deficit. This reduction is counterbalanced in the long term by an improvement in the trade balance. The government budget is characterized by long-term declines in overall income- and expenditure-to-GDP ratios, and by a long-term decline in the domestic borrowing requirement, which allows for crowding-in of private investment. Government transfers to the pension system do not change significantly. Looking at the overall pension system, pension payments increase only slightly in the long run. An increase in the number of retirees is evened out by a drop in the pension benefit rate. The increase in the number of retirees follows from increased private sector (skilled) employment, whereas the reduction in the pension benefit rate follows from declining formal sector prices associated with the strong formal sector supply response.

\subsection{A Composite Reform Program}

Finally, we consider a composite, "realistic" package of policies, which combines reductions in payroll taxes on unskilled labor with a reduction in unions' bargaining strength, and a cut in unskilled employment in the public sector. We assume that the payroll tax on unskilled labor is reduced by 5 percentage points, the number of unskilled workers in the public sector is reduced by 5 percent, and that the bargaining strength of trade unions is reduced from an initial level of 0.7 to a "neutral" value of 0.6 . We consider the three alternative budget closure rules specified above, but to save space we do not report the results graphically.

Given that the transmission channels of each of the individual components of the composite program have been described extensively in previous

sections, we restrict our attention here to the impact and long-run effects of the program on growth and unemployment. Simulation results with a non- 
neutral public deficit closure do not show evidence of large nonlinear effects. Specifically, the impact and long-term effects on the growth rate of aggregate real value added amount to 0.2 and 0.9 percent, respectively. This is approximately equal to the sum of the growth rates derived from the individual simulations described earlier. Similarly, the impact and long-term effects on private formal sector employment are very close to linear, amounting to -0.1 and 4.0 percent respectively for unskilled labor, and 3.2 and 3.1 percent respectively for skilled labor. Unskilled employment increases slightly by 0.2 percent when income taxes are used to keep the public deficit unchanged. Overall, although the simultaneous implementation of the individual components of the above specified policy reform package does bring some benefits (suggesting therefore that complementarity between labor market policies is desirable from an economic point of view, independently of other, political economy considerations) the impact of a "realistic" package of labor market reforms on growth and employment does not appear to be large. This has important implications for the design of adjustment programs in a region where the challenge is not only to reduce an existing high level of unemployment, but also to create sufficient jobs to absorb new entrants in the labor force.

\section{Summary and Policy Lessons}

The purpose of this paper has been to analyze the impact of labor market reforms on growth, real and relative wages, and the composition of employment and unemployment in labor-exporting MENA countries. We first provided a brief overview of the main features of the labor market in some of these countries. We then presented a simulation model, based on the IMMPA framework developed by Agénor (2003), Agénor, Izquierdo and Fofack (2003), and Agénor, Fernandes, and Haddad (2003), which captures many of these features (such as a large informal urban sector, a significant role of public sector employment and "leadership effects" of public sector wages, powerful trade unions, and international migration of labor), as well as other important structural characteristics of these countries (such as a pay-as-you-go pension system). After discussing the calibration procedure and our choices of parameter values, we presented and discussed a series of simulation experiments. We focused on a reduction in payroll taxation on unskilled labor, reductions in public sector wages and workforce, an increase in employment subsidies to 
the private sector, changes in the bargaining strength of trade unions, and a composite reform package involving several of these policies. In the case of payroll taxation, employment subsidies and the composite package, we considered both neutral and non-neutral changes. Specifically, we considered three alternative fiscal "closure" rules. In the first, we assumed no offsetting change in revenue, and the government borrows domestically to balance its budget-implying full crowding out of private investment. In the second and third, the policy is budget-neutral, and the government raises respectively sales taxes on the private, formal sector good, and income taxes on capitalist-rentier households, to cover increased expenditures (due to an increased deficit in the pension system and increased labor subsidy payments). Therefore, there is no crowding out of private capital formation in the second and third experiments.

There are a number of policy lessons that emerge from our results. For instance, we found that, regardless of how a cut in payroll taxes on unskilled labor is financed (either by borrowing from the private sector, or by implementing revenue-neutral changes in sales or income taxation), reduced labor costs lead to increased employment of unskilled labor, as well as substitution away from skilled labor (and physical capital) in the private formal sector. A decrease in skilled labor wages - resulting from a rise in skilled unemployment - partly offsets the tax-induced increase in the differential between skilled and unskilled labor costs. The net increase in the labor cost differential is still very significant in the longer term, implying a strong substitution away from skilled labor toward unskilled labor even in the long run. At the same time, our results showed that the overall rate of output growth varies significantly across experiments - essentially because the behavior of private investment depends very much (as could be expected) on whether or not there are offsetting changes in taxes. When the increase in the budget deficit resulting from a cut in the payroll tax is financed through domestic borrowing, private investment is crowded out; the lower rate of capital accumulation has an adverse effect on growth and thus on the demand for both categories of labor. Thus, the indirect or "level" effect on the demand for unskilled labor may mitigate significantly the substitution effect triggered by the change in relative labor costs. The results associated with a reduction in trade unions' bargaining power in wage negotiations also indicate large long-term gains in overall employment associated with general equilibrium effects.

The main policy lessons of our simulation experiments can be summarized 
as follows. The first is that, in assessing the impact of labor market reforms on growth and unemployment, it is important to account not only for the direct (partial equilibrium) effects of these policies, but also for their indirect (general equilibrium) effects on income and aggregate demand (resulting from changes in the government budget). For instance, it has been argued that a policy of subsidizing employment in the private sector would help to reduce unemployment in MENA countries. A simple, partial equilibrium analysis of this policy is indeed unambiguous: by lowering the relative cost of unskilled labor, a subsidy leads to an increase in the demand for that category of labor, which may be particularly significant if wages are fixed (as a result, say, of a binding minimum wage). As long as the increase in labor demand does not prompt greater participation in the labor force (that is, if unskilled labor supply is fairly inelastic), unskilled unemployment is thus likely to fall.

However, a partial equilibrium view can be misleading. The increase in subsidies must be financed, and this can occur in a variety of ways. Our experiments indicate that general equilibrium effects can be significant, even with a fairly neutral investment specification. Accordingly, if spending is kept constant, and the government chooses to let its fiscal deficit increase and borrow from the rest of the economy, this can have a large crowding-out effect on private investment, if private savings do not adjust quickly; the fall in investment may, over time, restrain the expansion of demand for all categories of labor - including unskilled labor. Thus, the longer-run effect of the policy on employment may be either nil or negative. Similarly, an increase in, say, taxes on capitalist-rentier households may restrain private capital formation and have an adverse effect on employment in the medium and the long run. More specifically, our general equilibrium analysis indicates that the overall impact of a change in payroll taxes on the demand for unskilled labor may be compounded, or mitigated, depending on how the government chooses to adjust its tax and spending instruments to maintain a balanced budget. In the presence of large crowding-out effects on private investment (and possibly savings), the direct gains (in terms of higher employment) associated with a reduction in payroll taxes may be highly mitigated. Similarly, whether employment subsidies end up reducing open unemployment in the formal sector may depend on the extent to which a higher perceived probability of finding a job in that sector affects workers' decision to remain in the informal sector.

The second policy lesson is that our simulation results indicate that a "piecemeal" approach to labor market reforms is unlikely to bring substantial 
benefits in terms of growth and employment. By contrast, a comprehensive approach will bring broad-based growth and reductions in both skilled and unskilled unemployment. The idea that labor market reform programs must be sufficiently broad (in the sense of covering a wide range of complementary policies) and deep (of substantial magnitude) to have much of an effect is emphasized by Coe and Snower (1997) and Orszag and Snower (1998). At the same time, however, although a "realistic" package of policies (which combines reductions in payroll taxes on unskilled labor, a reduction in unions' bargaining strength, and a cut in unskilled employment in the public sector) may have a significant impact on the composition of employment in laborexporting MENA countries, fostering a sustained increase in growth rates and job creation in these countries may require a more comprehensive program of structural reforms - involving, in particular, financial sector reforms, privatization, and measures aimed at increasing private sector participation. 


\section{Appendix A}

\section{List of Equations ${ }^{19}$}

\section{PRODUCTION}

$$
\begin{gathered}
X_{j}=V_{j}+X_{j} \sum_{i} a_{i j} \\
V_{A}=\left[\alpha_{X A}\left\{\beta_{X A} U_{A}^{-\rho_{X A}}+\left(1-\beta_{X A}\right) K_{G}{ }^{-\rho_{X A}}\right\}^{-\frac{1}{\rho_{X A}}}\right]^{1-\eta_{X A}} \\
X_{A}=\alpha_{T A}\left\{\beta_{T A} E_{A}^{\rho_{T A}}+\left(1-\beta_{T A}\right) D_{A}^{\rho_{T A}}\right\}^{\frac{1}{\rho_{T A}}} \\
V_{I}=\alpha_{X I} U_{I}^{\beta_{X I}} \\
V_{G}=\alpha_{X G}\left\{\beta_{X G} U_{G}^{-\rho_{X G}}+\left(1-\beta_{X G}\right) S_{G}{ }^{-\rho_{X G}}\right\}^{-\frac{1}{\rho_{X G}}} \\
V_{P}=\alpha_{X P}\left\{\beta_{X P} T_{1}^{-\rho_{X P}}+\left(1-\beta_{X P}\right) K_{G}^{-\rho_{X P}}\right\}^{-\frac{1}{\rho_{X P}}} \\
T_{1}=\alpha_{X P 1}\left\{\beta_{X P 1} T_{2}^{-\rho_{X P 1}}+\left(1-\beta_{X P 1}\right) U_{P}^{-\rho_{X P 1}}\right\}^{-\frac{1}{\rho_{X P 1}}} \\
T_{2}=\alpha_{X P 2}\left\{\beta_{X P 2} S_{P}^{-\rho_{X P 2}}+\left(1-\beta_{X P 2}\right) K_{P}^{-\rho_{X P 2}}\right\}^{-\frac{1}{\rho_{X P 2}}} \\
X_{P}=\alpha_{T P}\left\{\beta_{T P} E_{P}^{\rho_{T P}}+\left(1-\beta_{T P}\right) D_{P}^{\rho_{T P}}\right\}^{\frac{1}{\rho_{T P}}}
\end{gathered}
$$

\section{EMPLOYMENT}

$$
\begin{gathered}
U_{R}=U_{R,-1}\left(1+g_{R}\right)-M I G \\
U_{A}^{d}=\left(V_{A}^{1+\frac{\rho_{X A}}{1-\eta_{X A}}}\left(1-\eta_{X A}\right)\left(\frac{P V_{A}}{W_{A}}\right) \frac{\beta_{X A}}{\alpha_{X A}^{\rho_{X A}}}\right)^{\frac{1}{1+\rho_{X A}}} \\
U_{R}^{s}=U_{A}^{d}\left(V_{A}, \frac{W_{A}}{P V_{A}}\right) .
\end{gathered}
$$

\footnotetext{
${ }^{19}$ Unless otherwise indicated, the indexes $i$ and $j$, with $i, j=A, I, P, G$ refer to production sectors and $h=A, I, F, K R$ to households.
} 


$$
\begin{aligned}
& U_{P}^{d}=T_{1}\left(\frac{P T_{1}}{\left(1+p \operatorname{tax}_{U}\right) W_{M}-E S_{U}} \frac{\beta_{X P 1}}{\alpha_{X P 1}^{\rho_{X P 1}}}\right)^{\sigma_{X P 1}} \\
& \frac{U_{F}^{s}}{U_{F,-1}^{s}}=\left\{\frac{U_{P,-1}^{d}}{U_{F,-1}^{s}-U_{G,-1}}\left(\frac{W_{M,-1}}{W_{I,-1}}\right)\right\}^{\beta_{F}} \\
& U_{U}=U_{U,-1}\left(1+g_{U}-\delta_{N P}^{U}\right)+M I G-S K L-I M I G \\
& U_{G}=\left(1+g_{U G}-\delta_{N P}^{U}\right) U_{G,-1} \\
& U_{I}^{s}=U_{U}-U_{F}^{s} \\
& S_{P}^{d}=T_{2} \kappa_{S}\left(\frac{P T_{2}}{\left(1+p t a x_{S}\right) W_{S}-E S_{S}} \frac{\beta_{X P 2}}{\alpha_{X P 2}^{\rho_{X P 2}}}\right)^{\sigma_{X P 2}} \\
& U N E M P_{S}=1-\frac{\left(S_{G}^{T}+S_{P}^{d}\right)}{S} \\
& U N E M P_{U}=1-\frac{\left(U_{G}+U_{P}^{d}\right)}{U_{F}^{s}} \\
& W_{M}=w_{M} P_{F} \\
& W_{I}=\beta_{X I}\left(\frac{P V_{I} V_{I}}{U_{I}^{s}}\right) \\
& W_{U G}=\omega_{U G} P_{F} \\
& \frac{W_{S}}{W_{S}-\Omega_{0} U N E M P_{S}^{-\phi_{1}} W_{S G}^{\phi_{2}}}-\varepsilon_{S_{P}^{d} / W_{S}}-\frac{W_{S} S_{P}^{d}}{\nu P R O F_{P}}=0 \\
& W_{S G}=\omega_{S G} P_{F} \\
& M I G=U_{R,-1} \lambda_{m}\left[\sigma_{M} \ln \left(\frac{E w_{U}}{E w_{A}}\right)\right]+\left(1-\lambda_{m}\right) \frac{U_{R,-1}}{U_{R,-2}} M I G_{-1} \\
& E w_{U}=\frac{\theta_{U} W_{M,-1}+\left(1-\theta_{U}\right) W_{I,-1}}{P_{U R B,-1}} \\
& \theta_{U}=\frac{U_{P,-1}}{U_{F,-1}^{s}-U_{G,-1}} \\
& E w_{A}=\frac{W_{A,-1}}{P_{R,-1}}
\end{aligned}
$$




$$
\begin{gathered}
I M I G=U_{U,-1} \lambda_{i m} \sigma_{I M} \ln \left(\frac{E w_{F}}{E w_{U}}\right)+\left(1-\lambda_{i m}\right) \frac{U_{U,-1}}{U_{U,-2}} I M I G_{-1} \\
E w_{F O R}=\frac{E R \cdot W_{F O R,-1}}{P_{U R B,-1}} \\
S K L=\left[\beta_{E}\left(\varphi S_{G}^{E}\right)^{-\rho_{E}}+\left(1-\beta_{E}\right) K_{E}{ }^{-\rho_{E}}\right]^{-\frac{1}{\rho_{E}}} \\
\varphi=1-\varphi_{m}\left[\frac{\left(1-U N E M P_{S,-1}\right) W_{S,-1}}{W_{S G,-1}}\right]^{\delta_{E}} \\
S_{G}^{T}=\left(1+g_{S G}-\delta_{N P}^{S}\right) S_{G,-1}^{T} \\
S=\left(1-\delta_{S}-\delta_{N P}^{S}\right) S_{-1}+S K L
\end{gathered}
$$

SUPPLY AND DEMAND

$$
\begin{gathered}
I N T_{j}=\sum_{i} a_{j i} X_{i} \\
Q_{A}^{s}=\alpha_{Q A}\left\{\beta_{Q A} M_{A}^{-\rho_{Q A}}+\left(1-\beta_{Q A}\right) D_{A}^{-\rho_{Q A}}\right\}^{-\frac{1}{\rho_{Q A}}} \\
Q_{I}^{s}=X_{I} \\
Q_{G}^{s}=X_{G} \\
Q_{P}^{s}=\alpha_{Q P}\left\{\beta_{Q P} M_{P}^{-\rho_{Q P}}+\left(1-\beta_{Q P}\right) D_{P}^{-\rho_{Q P}}\right\}^{-\frac{1}{\rho_{Q P}}} \\
Q_{A}^{d}=C_{A}+G_{A}+I N T_{A} \\
Q_{I}^{d}=C_{I}+I N T_{I} \\
Q_{G}^{d}=C_{G}+G_{G}+Z_{P}^{G}+I N T_{G} \\
Q_{P}^{d}=C_{P}+G_{P}+\left(Z_{P}^{P}+Z_{G}\right)+I N T_{P} \\
\sum_{h} C_{i h}=\sum_{h} x_{i h}+\frac{\sum_{h} c c_{i h}\left(C O N_{h}-\sum_{i} P Q_{i} x_{i h}\right)}{P Q_{i}} \\
G_{j}=g g_{j} \frac{N G}{P Q_{j}}, \quad \sum_{P} g g_{j}=1, \text { for } j=A, G, P \\
Z_{P}^{j}=z z_{j} \frac{P K}{P Q_{i}}, \quad \sum z z_{j}=1, \text { for } j=G, P \\
\sum
\end{gathered}
$$




\section{TRADE}

$$
\begin{aligned}
& E_{i}=D_{i}\left(\frac{P E_{i}}{P D_{i}} \cdot \frac{1-\beta_{T i}}{\beta_{T i}}\right)^{\sigma_{T i}}, \text { for } i=A, P \\
& M_{i}=D_{i}\left(\frac{P D_{i}}{P M_{i}} \cdot \frac{\beta_{Q i}}{1-\beta_{Q i}}\right)^{\sigma_{Q i}}, \text { for } i=A, P
\end{aligned}
$$

\section{PRICES}

$$
\begin{gathered}
P V_{i}=V_{i}^{-1}\left\{P X_{i}\left(1-i n d t a x_{i}\right)-\sum_{j} a_{j i} P Q_{j}\right\} X_{i} \\
P E_{i}=w p e_{i} E R, \text { for } i=A, P \\
P M_{i}=w p m_{i}\left(1+t m_{i}\right) E R, \text { for } i=A, P \\
P X_{i}=\frac{P D_{i} D_{i}+P E_{i} E_{i}}{X_{i}}, \text { for } i=A, P \\
P Q_{i}=\frac{P D_{i} D_{i}+P M_{i} M_{i}}{Q_{i}}, \text { for } i=A, P \\
P Q_{i}=P X_{i}=P D_{i}, \text { for } i=I, G \\
P_{R}=\sum_{i} w r_{i} P Q_{i}, \text { with } \sum_{i} w r_{i}=1 \\
P K=\frac{\sum_{i} P Q_{i} Z_{i}}{Z}=\frac{P Q_{G} Z_{P}^{G}+P Q_{P} Z_{P}^{P}}{Z} \\
P T_{2}=\frac{P R O F_{P}+\left[\left(1+p t a x_{S}\right) W_{S}-E S_{S}\right] S_{P}}{P_{i} P f_{i}, \text { with } \sum_{i} w f_{i}=1} \\
P T_{1}=\frac{T_{2} P T_{2}+\left[\left(1+p t a x_{U}\right) W_{M}-E S_{U}\right] U_{P}}{\sum_{i} w u_{i} P Q_{i}, \text { with } \sum_{i} w u_{i}=1} \\
P T_{i}=1
\end{gathered}
$$




\section{INCOME}

$$
\begin{gathered}
P R O F_{i}=P V_{i} V_{i}-W_{i} U_{i}, \text { for } i=A, I \\
P R O F_{P}=\begin{array}{c}
P V_{P} V_{P}-\left[\left(1+p t a x_{U}\right) W_{M}-E S_{U}\right] U_{P} \\
-\left[\left(1+p \operatorname{tax}_{S}\right) W_{S}-E S_{S}\right] S_{P}
\end{array} \\
Y F_{i}=P R O F_{i}, \text { for } i=A, I \\
Y F_{P}=(1-e n t a x) P R O F_{P}-I F \cdot E R \cdot F L_{P,-1} \\
Y H_{A}=\gamma_{A} T R H+P V_{A} V_{A} \\
Y H_{I}=\gamma_{I} T R H+P V_{I} V_{I}+\left(1-\tau_{F}\right) E R \cdot R E M I T \\
Y H_{F}={ }_{P N S I O N S+\gamma_{F} T R H+\left(W_{M} U_{P}+W_{U G} U_{G}\right)}+\left(W_{S} S_{P}+W_{S G} S_{G}\right)+\tau_{F} E R \cdot R E M I T \\
Y H_{K R}=\gamma_{K R} T R H+(1-r e) Y F_{P}
\end{gathered}
$$

CONSUMPTION, SAVINGS, AND INVESTMENT

$$
\begin{gathered}
S A V_{h}=s r_{h}\left(1-\operatorname{inctax}_{h}\right) Y H_{h} \\
C O N_{h}=\left(1-\text { inctax }_{h}\right) Y H_{h}-S A V_{h}
\end{gathered}
$$

$P K \cdot Z_{P}+P Q_{P} Z_{G}=r e \cdot Y F_{P}+\sum_{h} S A V_{h}-C D E F+E R\left(\Delta F L_{P}+\Delta F L_{G}\right)$

$$
K_{P}=\left(1-\delta_{P}\right) K_{P,-1}+Z_{P,-1}
$$

\section{GOVERNMENT}

$$
\begin{aligned}
-C D E F= & T X R E V-T R H-T R S O C-W_{S G} S_{G}^{E} \\
& -N G-I F_{G} E R \cdot F L_{G,-1} \\
- & O D E F=-C D E F-P Q_{P} Z_{G}
\end{aligned}
$$




$$
\begin{aligned}
T X R E V= & \sum_{i=A, P} \text { wpm }_{i} \operatorname{tm}_{i} M_{i} E R+\operatorname{ptax}_{U} W_{M} U_{P}^{d}+\operatorname{ptax}_{S} W_{S} S_{P}^{d}(\mathrm{~A} 77) \\
& +\sum_{i} \text { indtax }_{i} P X_{i} X_{i}+\text { entax } \cdot P R O F_{P}+\operatorname{inctax}_{R} Y H_{R} \\
& + \text { inctax }_{A} Y H_{A}+\text { inctax }_{F} Y H_{F}-E S_{U} U_{P}^{d}-E S_{S} S_{P}^{d} \\
& P Q_{P} Z_{G}=I_{I N F}+I_{E}+I_{H} \\
K_{i}= & \left(1-\delta_{i}\right) K_{i,-1}+\frac{I_{i,-1}}{P Q_{P,-1}}, \text { where } i=I N F, H, E \\
& K_{G}=\alpha_{G}\left\{\beta_{G} K_{I N F}^{-\rho_{G}}+\left(1-\beta_{G}\right) K_{H}^{-\rho_{G}}\right\}^{-\frac{1}{\rho_{G}}}
\end{aligned}
$$

\section{PENSION SYSTEM}

$$
\begin{gathered}
\text { TRSOC }=\text { PENSIONS }-\operatorname{ptax}_{U} U_{P}^{d}-\operatorname{ptax}_{S} S_{P}^{d} \\
B E N E F=B E N E F_{-1}\left(1+\Delta \ln P_{F,-1}\right) \\
N U M P E N=\left(1-\delta_{N}\right) N U M P E N_{-1}+N E W P E N \\
N E W P E N=\delta_{N P}^{U}\left(U_{P,-1}^{d}+U_{G,-1}\right)+\delta_{N P}^{S}\left(S_{P,-1}^{d}+S_{G,-1}^{T}\right) \\
P E N S I O N S=B E N E F \cdot N U M P E N
\end{gathered}
$$

\section{BALANCE OF PAYMENTS}

$$
\begin{gathered}
0=\sum_{i=A, P}\left(w p e_{i} E_{i}-w_{p m} M_{i}\right)+R E M I T-I F \cdot F L_{P,-1} \\
-I F_{G} F L_{G,-1}+\Delta F L_{G}+\Delta F L_{P} \\
R E M I T=W_{F O R} F O R L_{-1} \\
F O R L=\left(1-\delta_{I M I G}\right) F O R L_{-1}+I M I G
\end{gathered}
$$




\title{
Appendix B \\ Variable Names and Definitions ${ }^{20}$
}

\author{
Endogenous Variables \\ $B E N E F \quad$ Average pension benefit \\ $C_{i} \quad$ Consumption of good $i$ by the urban and rural private sector \\ $C_{i h} \quad$ Consumption of good $i$ by household $h$ \\ $C O N_{h} \quad$ Total nominal consumption by household $h$ \\ $C D E F \quad$ Current public budget deficit \\ $D_{i} \quad$ Domestic demand for good $i=A, P$ \\ $E_{i} \quad$ Export of traded goods for $i=A, P$ \\ $E S_{S} \quad$ Nominal employment subsidy on skilled labor \\ in the private sector \\ $E S_{U} \quad$ Nominal employment subsidy on unskilled labor \\ in the private sector \\ $E w_{U} \quad$ Expected urban unskilled wage \\ $E w_{A} \quad$ Expected agricultural wage \\ FORL Stock of domestic workers abroad \\ $G_{i} \quad$ Government spending on good $i=A, G, P$ \\ $I M I G \quad$ International migration \\ $I N T_{i} \quad$ Intermediate good demand for good $i$ \\ $K_{E} \quad$ Public capital in education \\ $K_{G} \quad$ Total Public capital \\ $K_{H} \quad$ Public Capital in health \\ $K_{I N F} \quad$ Public capital in infrastructure \\ $K_{P} \quad$ Private capital \\ $M_{i} \quad$ Imports of good $i=A, P$ \\ $M I G \quad$ Migration to urban area \\ $N E W P E N \quad$ Flow of skilled and unskilled workers retiring in each period \\ NUMPEN Number of pensioners \\ $O D E F \quad$ Overall budget deficit \\ $P_{F} \quad$ Formal urban price index \\ $P_{R} \quad$ Rural price index \\ $P_{S} \quad$ Price index for skilled labor \\ $P_{U R B} \quad$ Urban price index

\footnotetext{
${ }^{20}$ Unless otherwise indicated, the index $i=A, I, P, G$ refers to production sectors and $h=A, I, F, K R$ to households.
} 


\begin{tabular}{ll}
$P D_{i}$ & Domestic price of domestic sales of good $i=A, P$ \\
$P E_{i}$ & Price of exported good $i=A, P$ \\
$P E N S I O N S$ & Total amount of pension paid to pensioners \\
$P K$ & Price of capital \\
$P M_{i}$ & Price of imported good $i=A, P$ \\
$P Q_{i}$ & Composite good price of good $i$ \\
$P R O F_{i}$ & Profits by firms in sector $i=A, I, P$ \\
$P T_{1}$ & Price of composite input $T_{1}$ \\
$P T_{2}$ & Price of composite input $T_{2}$ \\
$P V_{i}$ & Value added price of good $i$ \\
$P X_{i}$ & Sales price of good $i$ \\
$Q_{i}^{s}, Q_{i}^{d}$ & Composite supply and demand of good $i$ \\
$R E M I T$ & Foreign-currency value of the flow of remittances \\
& from abroad \\
$S$ & Skilled workers \\
$S_{P}^{d}$ & Demand for skilled workers in private urban formal \\
$S A V_{h}$ & sector \\
$s r_{h}$ & Saving by household $h$ \\
$S K L$ & Saving rate for household $h$ \\
$S_{P}$ & New skilled workers \\
$T_{1}$ & Skilled labor employed in private urban formal \\
$T_{2}$ & Composite input from $T_{2}$ and unskilled labor \\
$T R H$ & Composite input from capital and skilled labor \\
$T R S O C$ & Transfers to households \\
$T X R E V$ & Net government pension transfers \\
$U_{i}$ & Tax revenues \\
$U_{R}$ & Unskilled labor employed in sector $i=A, I, P$ \\
$U_{R}^{s}$ & Unskilled workers in rural sector \\
$U_{U}$ & Unskilled labor supply in the rural sector \\
$U_{i}^{d}$ & Unskilled workers in urban sector \\
$U_{F}^{S}$ & Demand for labor in sector $i=A, I, P$ \\
$U_{I}^{S}$ & Unskilled labor supply in the urban formal sector \\
$U N E M P_{S}$ & Unskilled labor supply in the informal sector \\
$U N E M P_{U}$ & Skilled unemployment rate \\
$V_{i}$ & Unskilled unemployment rate in the formal sector \\
& Value added in sector $i$ \\
& \\
\hline &
\end{tabular}




\begin{tabular}{|c|c|}
\hline$W_{i}$ & Nominal wage for labor employed in sector $i=A, I$ \\
\hline$w_{i}$ & $\begin{array}{l}\text { Real wage rate for unskilled labor employed in sector } \\
i=A, I\end{array}$ \\
\hline$W_{M}$ & $\begin{array}{l}\text { Minimum wage (unskilled labor in urban formal } \\
\text { private sector) }\end{array}$ \\
\hline$w_{M}$ & $\begin{array}{l}\text { Real minimum wage (unskilled labor in urban formal } \\
\text { private sector) }\end{array}$ \\
\hline$W_{S}$ & $\begin{array}{l}\text { Nominal wage rate for skilled worker in the private urban } \\
\text { formal sector }\end{array}$ \\
\hline$w_{S}$ & $\begin{array}{l}\text { Real wage rate for skilled worker in the private urban formal } \\
\text { sector }\end{array}$ \\
\hline$W_{S G}$ & Nominal wage rate for skilled labor in the government sector \\
\hline$w_{S G}$ & Skilled wage in the public sector, real terms \\
\hline$W_{U G}$ & $\begin{array}{l}\text { Nominal wage rate for unskilled labor in the government } \\
\text { sector }\end{array}$ \\
\hline$w_{U G}$ & Unskilled wage in the public sector, real terms \\
\hline$x_{i h}$ & Subsistence level of consumption of good $i$ by household $h$ \\
\hline$X_{i}$ & Production of good $i$ \\
\hline$Y F_{i}$ & Income by firms in sector $i=A, I, P$ \\
\hline$Y H_{h}$ & Household income for household $h$ \\
\hline$Z$ & Total investment demand \\
\hline$Z_{i}$ & Investment demand for good $i=P, G$ \\
\hline$Z_{P}^{i}$ & Investment demand for good $i=P, G$ by formal private sector \\
\hline
\end{tabular}




\begin{tabular}{ll}
\multicolumn{2}{c}{ Exogenous Variables } \\
Name & Definition \\
in text & \\
entax & Corporate income tax \\
$E R$ & Nominal exchange rate \\
$E w_{F O R}$ & Expected real foreign wage (in terms of domestic prices) \\
$F L_{i}$ & Foreign loans to sector $i=G, P$ \\
$G_{C}$ & Government consumption \\
$g_{R}$ & Population growth in rural economy \\
$g_{S G}$ & Growth rate of the skilled labor force in the public sector \\
$g_{U G}$ & Growth rate of the unskilled labor force in the public sector \\
$g_{U}$ & Population growth in urban economy \\
$I_{E}$ & Investment in education \\
$I F$ & Foreign interest rate \\
$I F_{G}$ & Interest rate on government foreign loans \\
$I_{H}$ & Investment in health \\
$I_{I N F}$ & Investment in infrastructure \\
$i n c t a x_{h}$ & Income tax rate for $h$ \\
$i n d t a x_{i}$ & Rate of indirect taxation of output in sector $i$ \\
$N G$ & Total government current expenditure on goods and services \\
$p t a x_{S}$ & Payroll tax for skilled labor in private urban sector \\
$p_{a x}$ & Payroll tax for unskilled labor in private urban sector \\
$S_{G}$ & Skilled workers in public sector \\
$S_{G}^{E}$ & Skilled labor in the public sector engaged in education \\
$S_{G}^{T}$ & Total number of skilled workers in the public sector \\
$\operatorname{tm}_{i}$ & Import tariff for good $i=A, P$ \\
$U_{G}$ & Unskilled workers in public sector \\
$W_{F O R}$ & Nominal foreign wage \\
$w p e_{i}$ & World price of export for $i=A, P$ \\
$w p m_{i}$ & World price of import for $i=A, P$ \\
&
\end{tabular}




$\begin{array}{ll}\text { Parameters } \\ \text { Name } & \text { Definition } \\ \text { in text } & \text { Input-output coefficient } \\ a_{i j} & \text { Shift parameter in the public capital equation } \\ \alpha_{G} & \text { Shift parameter in the total supply function of good } i=A, P \\ \alpha_{Q i} & \text { Shift parameter in transformation function } \\ \alpha_{T i} & \text { between exported and domestic production of good } i=A, P \\ & \text { Shift parameter in production of good } i=A, I, P \\ \alpha_{X i} & \text { Shift parameter in composite input of unskilled } \\ \alpha_{X P 1} & \text { and skilled/capital composite input } \\ \alpha_{X P 2} & \text { Shift parameter in composite input of skilled workers and private } \\ & \text { capital } \\ \beta_{E} & \text { Parameter determining the weight of skilled labor in } \\ & \text { production of education } \\ \beta_{F} & \text { Speed of adjustment for the supply of unskilled labor in } \\ & \text { the formal private sector } \\ \beta_{G} & \text { Share parameter in the public capital equation } \\ \beta_{Q A} & \text { Shift parameter in agricultural composite good } \\ \beta_{Q P} & \text { Shift parameter in urban composite good } \\ \beta_{T i} & \text { Shift parameter between exported and domestic } \\ & \text { production of good } i=A, P \\ \beta_{X i} & \text { Shift parameter in production of good } i=A, I, P \\ \beta_{X P 1} & \text { Share parameter between unskilled and skilled/capital } \\ \beta_{X P 2} & \text { composite input } \\ c c_{i h} & \text { Share parameter between skilled workers and private capital } \\ \delta_{E} & \text { Shares of household } h \text { in consumption of good } i \\ \delta_{H} & \text { Depreciation rate of education capital } \\ \delta_{I N F} & \text { Depreciation rate of health capital } \\ \delta_{I M I G} & \text { Depreciation rate of infrastructure } \\ \delta_{N P}^{S} & \text { Rate of "attrition" of the stock of migrants } \\ \delta_{N P}^{U} & \text { Rate of unskilled retirement in the urban formal sector } \\ \delta_{E} & \text { Sensitivity of skilled effort level to relative wages } \\ \delta_{P} & \text { Depreciation rate of private capital } \\ \delta_{S} & \text { Rate of "depreciation" or "de-skilling" of the skilled labor } \\ & \end{array}$




\begin{tabular}{|c|c|}
\hline$\varepsilon_{S_{P}^{d} / W_{S}}$ & Wage elasticity of the demand for skilled labor \\
\hline$\varphi$ & Productivity of public workers engaged in providing education \\
\hline$\varphi_{m}$ & Minimum level of effort \\
\hline$\eta_{X A}$ & $\begin{array}{l}\text { Coefficient of returns to scale in the agricultural value } \\
\text { added function }\end{array}$ \\
\hline$\gamma_{h}$ & Share of transfers allocated to household $h$ \\
\hline$g g_{i}$ & Share of government expenditure on good $i=A, G, P$ \\
\hline$\kappa_{S}$ & Shift parameter for skilled private sector employment \\
\hline$\lambda_{i m}$ & Speed of adjustment in the international migration equation \\
\hline$\lambda_{m}$ & Partial adjustment rate on migration \\
\hline$\phi_{j}$ & $\begin{array}{l}\text { Parameters determining the nominal wage rate for the skilled labor } \\
\text { for } j=1,2\end{array}$ \\
\hline re & Percentage of profits retained \\
\hline$\rho_{E}$ & $\begin{array}{l}\text { Substitution parameter between skilled labor in production of } \\
\text { education and educational capital stock }\end{array}$ \\
\hline$\rho_{G}$ & Substitution parameter in the public capital equation \\
\hline$\rho_{Q i}$ & Substitution parameter in total supply of good $i=A, P$ \\
\hline$\rho_{T i}$ & $\begin{array}{l}\text { Substitution parameter between exported and domestic } \\
\text { production of good } i=A, P\end{array}$ \\
\hline$\rho_{X i}$ & Substitution parameter in production of good $i=A, P$ \\
\hline$\rho_{X P 1}$ & $\begin{array}{l}\text { Substitution parameter between unskilled and } \\
\text { skilled/capital composite input }\end{array}$ \\
\hline$\rho_{X P 2}$ & Substitution parameter between skilled workers and private capital \\
\hline$\sigma_{I M}$ & $\begin{array}{l}\text { Elasticity of international migration flows with respect to } \\
\text { expected wages }\end{array}$ \\
\hline$\sigma_{M}$ & Elasticity of migration flows with respect to expected wages \\
\hline$\sigma_{Q A}$ & Elasticity of agricultural composite good \\
\hline$\sigma_{Q P}$ & Elasticity of private urban composite good \\
\hline$\sigma_{S}$ & Elasticity of saving rate to deposit rate \\
\hline$\sigma_{T i}$ & $\begin{array}{l}\text { Elasticity of transformation between exported and domestic } \\
\text { production of good } i=A, P\end{array}$ \\
\hline$\sigma_{X P 1}$ & $\begin{array}{l}\text { Elasticity of substitution between unskilled workers } \\
\text { and composite input of skilled workers and private capital }\end{array}$ \\
\hline$\sigma_{X P 2}$ & Elasticity of substitution between skilled workers and private capital \\
\hline$\tau_{F}$ & $\begin{array}{l}\text { Fraction of remittances that are allocated to households in } \\
\text { the formal sector }\end{array}$ \\
\hline
\end{tabular}




$\begin{array}{ll}\theta_{U} & \text { Share of urban unskilled workers employed in formal sector } \\ v & \text { Measure of the trade union's bargaining power } \\ w f_{i} & \text { Initial share of good } i \text { in consumption of formal sector goods } \\ w r_{i} & \text { Relative weight of good } i \text { in rural consumption } \\ w u_{i} & \text { Initial share of good } i \text { in urban unskilled workers' consumption } \\ z z_{i} & \text { Share of investment expenditure on good } i=G, P\end{array}$




\section{References}

Abrahart, Alan, Iqbal Kaur, and Zafiris Tzannatos, "Government Employment and Active Labor Market Policies in MENA in a Comparative International Context," in Employment Creation and Social Protection in the Middle East and North Africa, ed. by Heba Handoussa and Zafiris Tzannatos, American University in Cairo Press (Cairo: 2002).

Agénor, Pierre-Richard, "The Labor Market and Economic Adjustment," IMF Staff Papers, 43 (June 1996), 261-335.

_ _ "Fiscal Adjustment and Labor Market Dynamics," unpublished, the World Bank (October 2002). Forthcoming, Journal of Development Economics.

—_, "Mini-IMMPA: A Framework for Assessing the Unemployment and Poverty Effects of Fiscal and Labor Market Reforms," Policy Research Working Paper No. 3067, the World Bank (May 2003).

—, The Economics of Adjustment and Growth, 2nd ed., forthcoming, Harvard University Press (Boston, Mass.: 2004).

Agénor, Pierre-Richard, and Karim El Aynaoui, "Labor Market Policies and Unemployment in Morocco: A Quantitative Analysis," Policy Research Working Paper No. 3091, the World Bank (June 2003).

Agénor, Pierre-Richard, Reynaldo Fernandes, and Eduardo Haddad, "Analyzing the Impact of Adjustment Policies on the Poor: An IMMPA Framework for Brazil," unpublished, the World Bank (June 2003).

Agénor, Pierre-Richard, Alejandro Izquierdo, and Hippolyte Fofack, "IMMPA: A Quantitative Macroeconomic Framework for the Analysis of Poverty Reduction Strategies," Policy Research Working Paper No. 3092, the World Bank (June 2003).

Assaad, Ragui, "The Effects of Public Sector Hiring and Compensation Policies on the Egyptian Labor Market," World Bank Economic Review, 11 (March 1997), 85-118.

— , "The Transformation of the Egyptian Labor Market: 1988-98," In The Egyptian Labor Market in an Era of Reform, ed. by Ragui Assaad, American University in Cairo Press (Cairo: 2002).

Assaad, Ragui, and Simon Commander, "Egypt," in Labour Markets in an Era of Adjustment, ed. by Susan Horton, Ravi Kanbur, and Dipak Mazumdar, the World Bank (Washington DC: 1994). 
Beetsma, Roel, Bettendorf, Leon, and Peter Broer, "The Budgeting and Economic Consequences of Ageing in the Netherlands," Economic Modelling, 20 (September 2003), 987-1013.

Booth, Alison L., The Economics of the Trade Union, Cambridge University Press (Cambridge: 1995).

Cavalletti, Barbara, and Eckhard Lubke, "Ageing Population and Pension Reform in Italy," in Policy Evaluation with Computable General Equilibrium, ed. by Amedeo Fossati and Wolfgang Wiegard, Routledge (London: 2002).

Coe, David T., and Dennis J. Snower, "Policy Complementarities: The Case for Fundamental Labor Market Reform," IMF Staff Papers, 44 (March 1997), $1-35$.

Farmer, K., and R. Wendner, "The Use of Multi Sector OLG-CGE Models for Policy Analysis," Research Memorandum No. 99-03, Department of Economics, University of Graz (March 1999).

Fehr, Hans, and Erling Ateigum, "Pension Funding Reforms in a Small Open Welfare State," in Policy Evaluation with Computable General Equilibrium, ed. by Amedeo Fossati and Wolfgang Wiegard, Routledge (London: 2002).

Glomm, Gerhard, and B. Ravikumar, "Flat-Rate Taxes, Government Spending on Education, and Growth," Review of Economic Dynamics, 1 (January 1998), 306-25.

Glystos, Nicholas P., "The Role of Migrant Remittances in Development: Evidence from Mediterranean Countries," International Migration, 40 (March 2002), 5-26.

_ - "A Macroeconometric Model of the Effects of Migrant Remittances in Mediterranean Countries," in Human Capital: Population Economics in the Middle East, ed. by Ismail Siraguldin, I. B. Tauris Publishers (London: 2003).

Harris, John, and Michael P. Todaro, "Migration, Unemployment and Development: A Two-Sector Analysis," American Economic Review, 60 (March 1970), 126-43.

Hollister, Robinson G., and Markus P. Goldstein, Reforming Labor Markets in the Near East: Implications for Structural Adjustment and Market Economies, ICS Press (San Francisco, Cal.: 1994).

International Labor Organization, Global Employment Trends, International Labor Office (Geneva: 2003).

Layard, Richard, Stephen Nickell, and Richard Jackman, Unemployment: Macroeconomic Performance and the Labor Market, Oxford University Press (Oxford: 1991). 
Norback, Pehr-Johan, "Cumulative Effects of Labor Market Distortions in a Developing Country," Journal of Development Economics, 65 (June 2001), $135-52$.

Orszag, Mike, and Dennis Snower, "Anatomy of Policy Complementarities," Swedish Economic Policy Review, 5 (Autumn 1998), 303-51.

Pissarides, Christopher A., "Labor Markets in the Middle East and North Africa," Discussion Paper No. 5, MENA Region, the World Bank (March 1993).

Pritchett, Lant, "Has Education had a Growth Payoff in the MENA Region?," Discussion Paper No. 18, MENA Region, the World Bank (June 1999).

Rama, Martin, "How Bad is Unemployment in Tunisia? Assessing Labor Market Efficiency in a Developing Country," World Bank Research Observer (February 1998), 59-77.

Said, Mona, "Public Sector Employment and Labor Markets in Arab Countries: Recent Developments and Policy Implications," in Labor and Human Capital in the Middle East, ed. by Djavad Salehi-Ishfahani, Ithaca Press (Reading, UK: 2001).

Salehi-Ishfahani, Djavad, Labor and Human Capital in the Middle East, Ithaca Press (Reading, UK: 2001).

Shaban, Radwan A., Ragui Assaad, and Sulayman Al-Qudsi, "Employment Experience in the Middle East and North Africa," in Labor and Human Capital in the Middle East, ed. by Djavad Salehi-Esfahani, Ithaca Press (Reading, UK: 2001).

Strand, Jon, "The Decline or Expansion of Unions: A Bargaining Model with Heterogeneous Labor," European Journal of Political Economy, 19 (June 2003), 317-40.

United Nations, Arab Human Development Report, International Labor Office (Geneva: 2003).

World Bank, MENA's Employment Challenge in the 21st Century: From Labor Force Growth to Job Creation, unpublished, the World Bank (January 2004). 


\section{Figure 1}

\section{Labor-Exporting MENA Countries: Economic and Labor Market Indicators}

Size of agricultural sector $(\%$ of GDP)

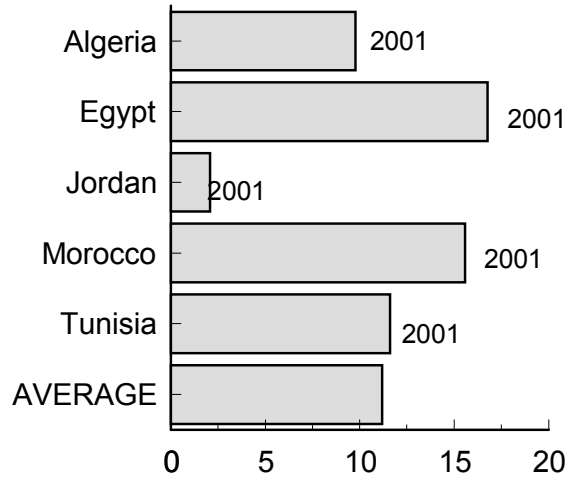

Employment in public sector (\% of total employment)

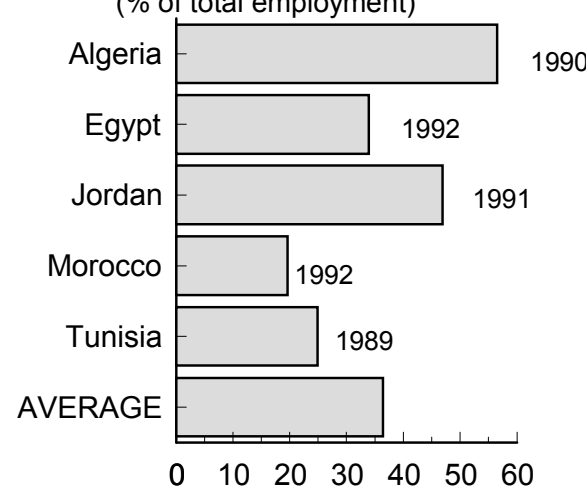

Public sector wage bill

(\% of public expenditure)

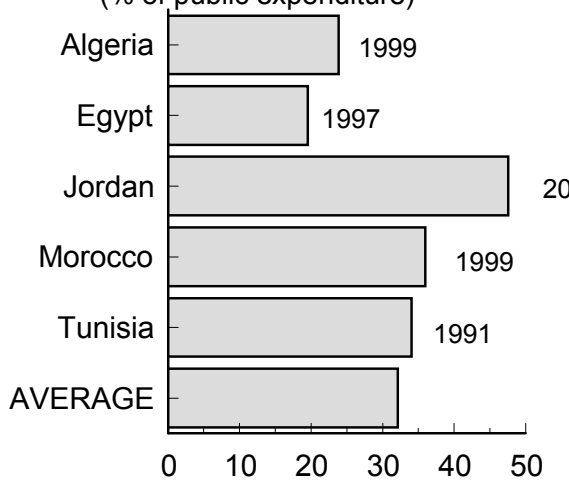

Workers remittances, net (in \% of GDP)

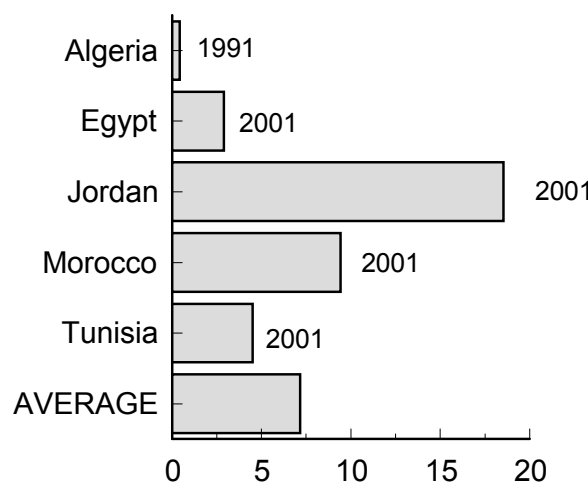

Employment in informal sector (\% of total employment)

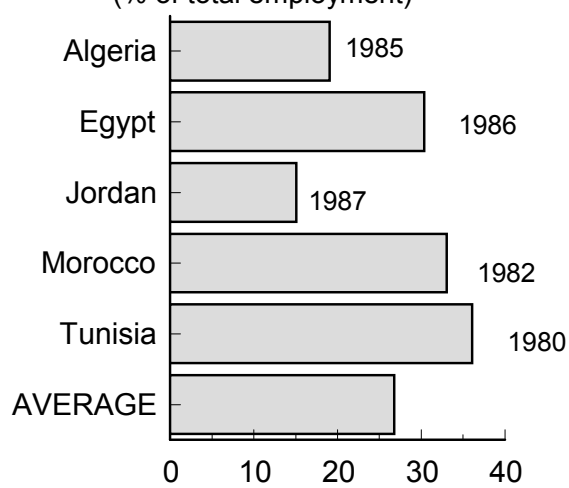

Labor force with primary education (\% of total)
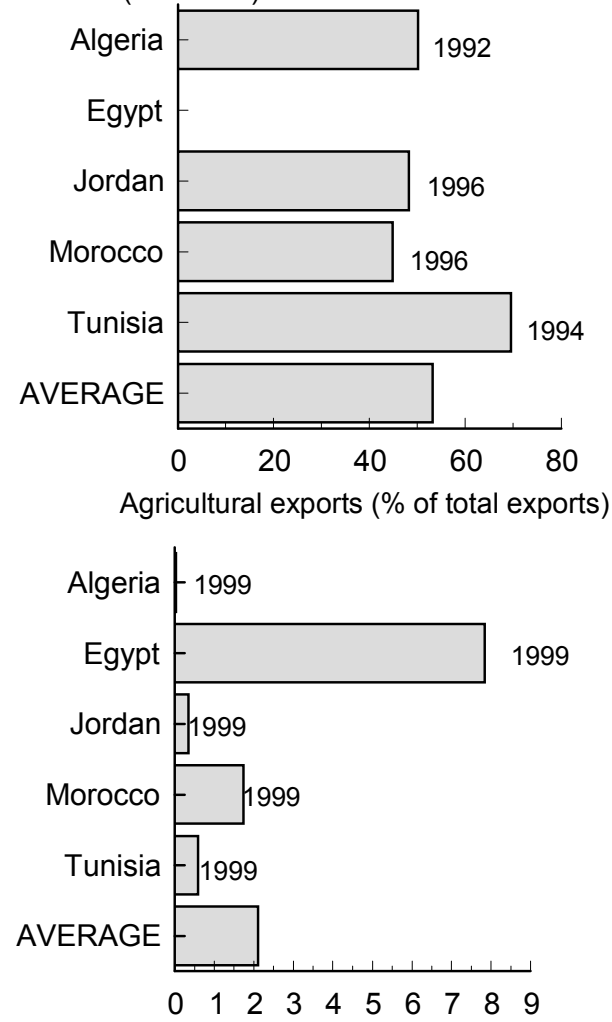

Degree of openness (total trade in \% of GDP)

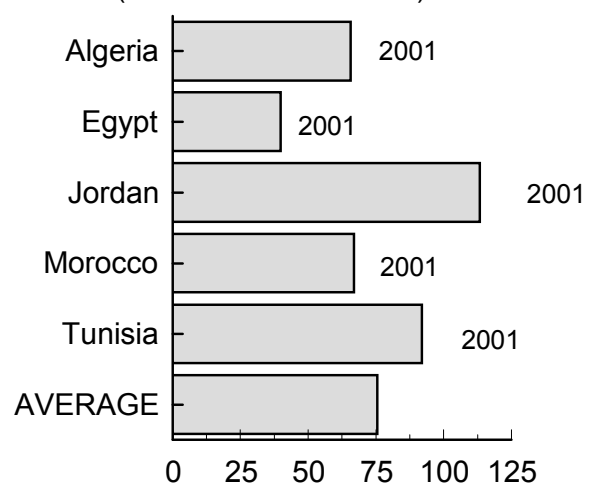

Note: Years are given next to bars. 
Figure 2

A Stylized View of the Labor Market in Labor-Exporting MENA Countries

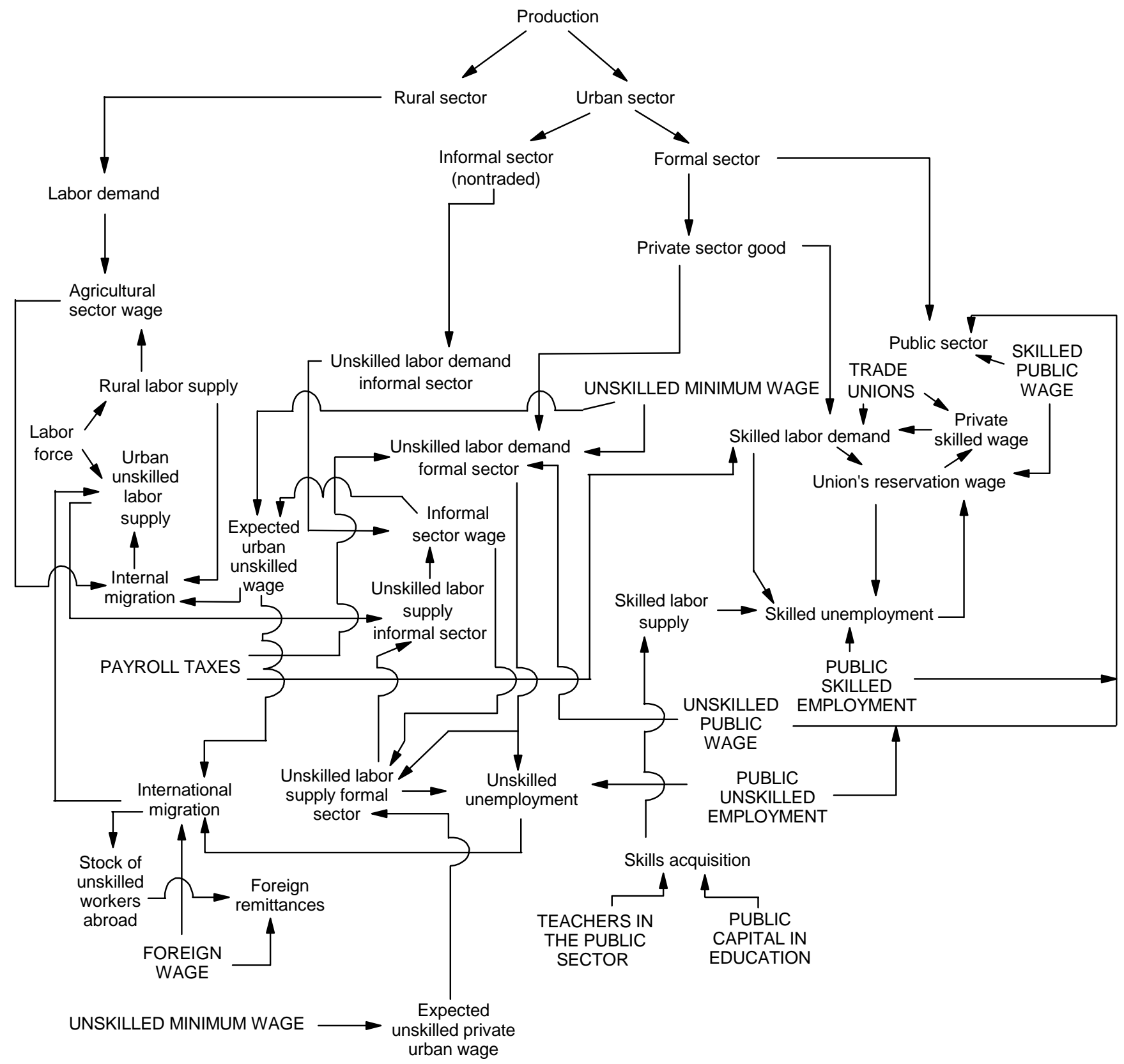


Figure 3

Simulation Results

\section{Percentage Reduction in Unskilled Labor Payroll Tax Rate (Percentage deviations from baseline, unless otherwise indicated)}
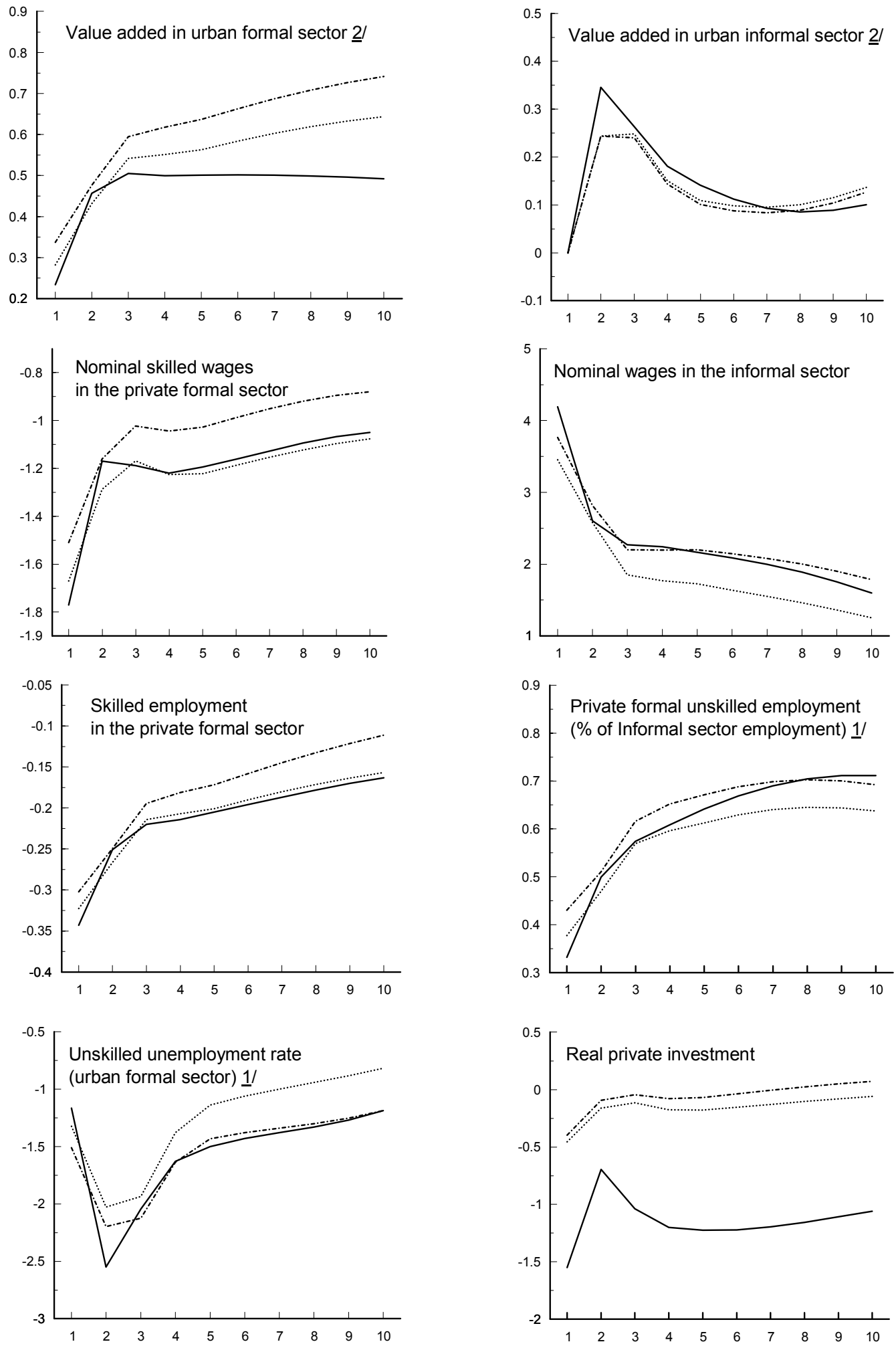

$1 /$ Absolute deviations from base line. 2/ Real terms. 
Figure 4

Simulation Results

5 Percentage Points Reduction in Public Sector Unskilled Labor Wage

(Percentage deviations from baseline, unless otherwise indicated)
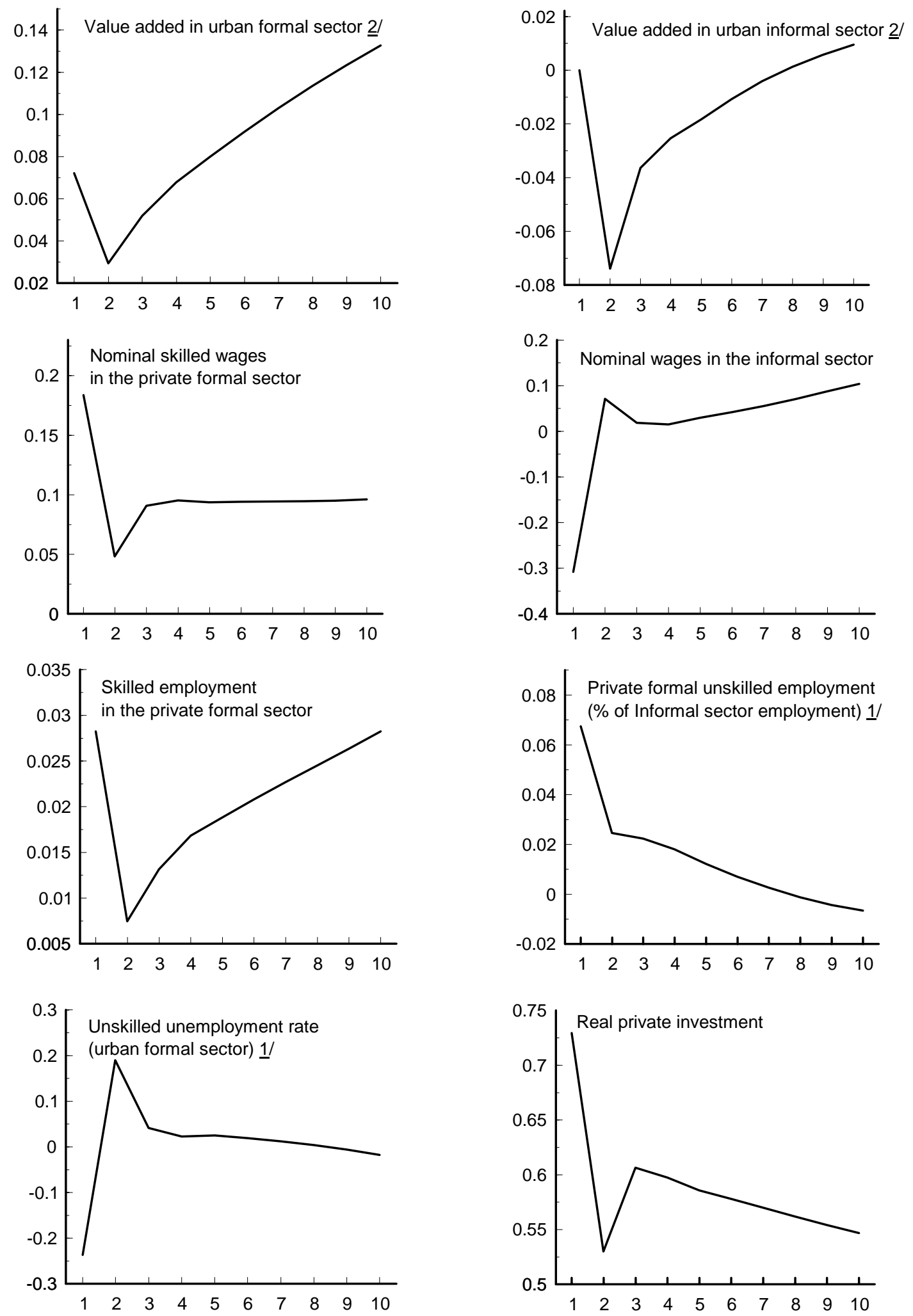

1/ Absolute deviations from base line. 2/ Real terms. 
Figure 5

Simulation Results

5 Percentage Points Reduction in Public Sector Skilled Labor Wage

(Percentage deviations from baseline, unless otherwise indicated)
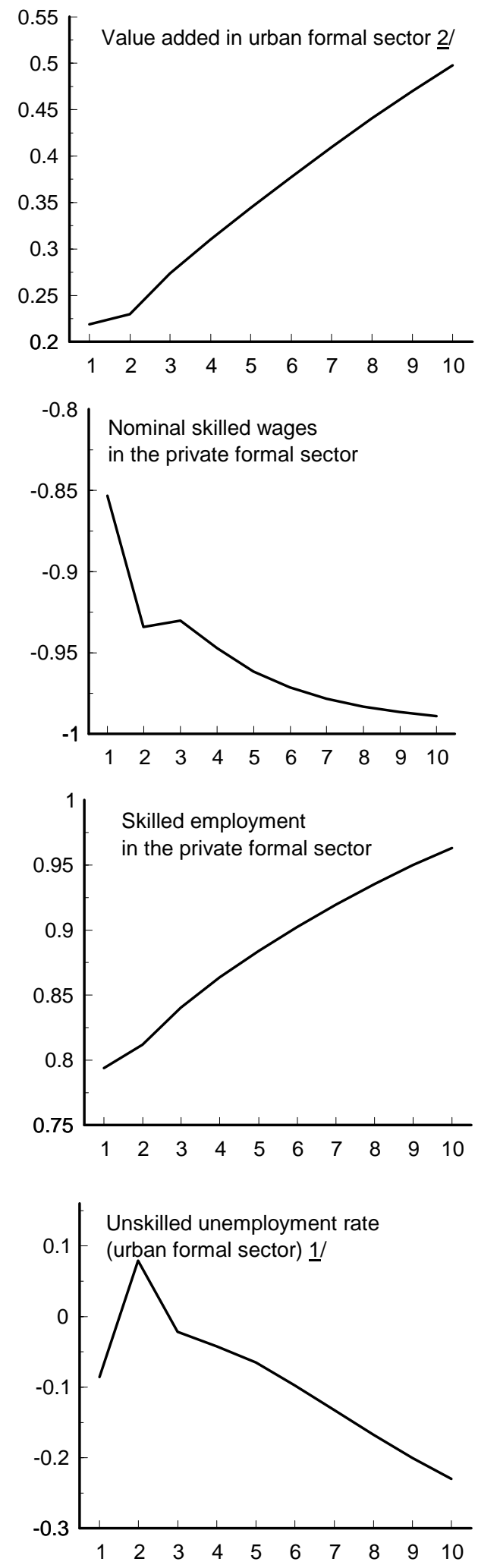
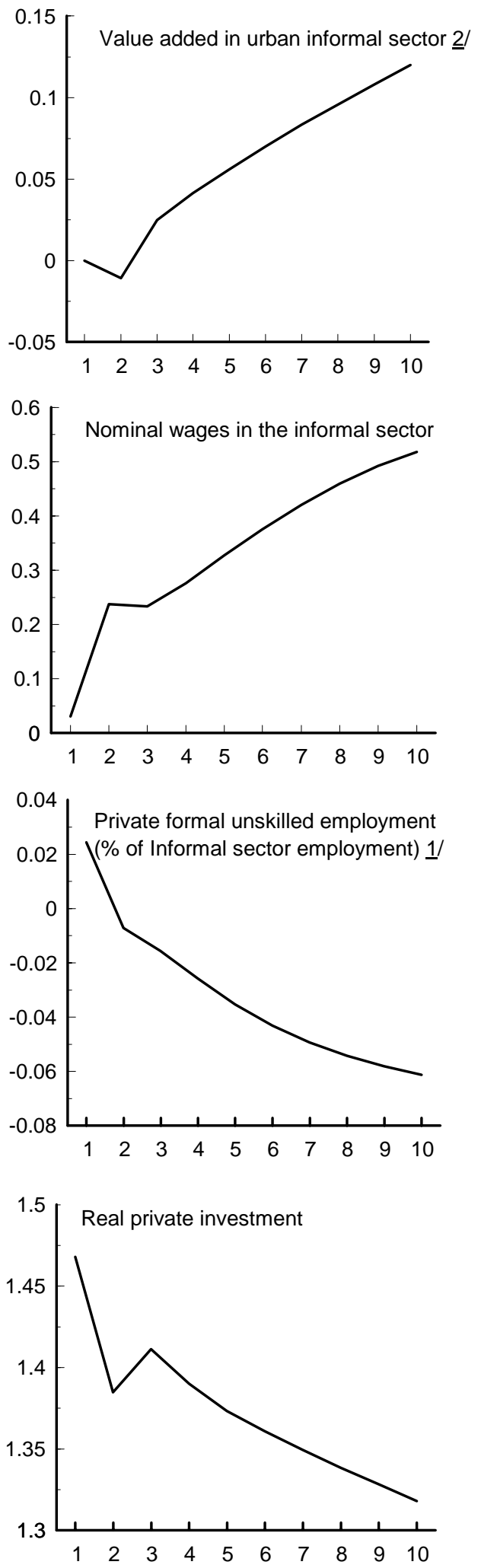

1/ Absolute deviations from base line. 2/ Real terms. 
Figure 6

Simulation Results

5 Percentage Points Reduction in Public Sector Unskilled Labor Employment (Percentage deviations from baseline, unless otherwise indicated)
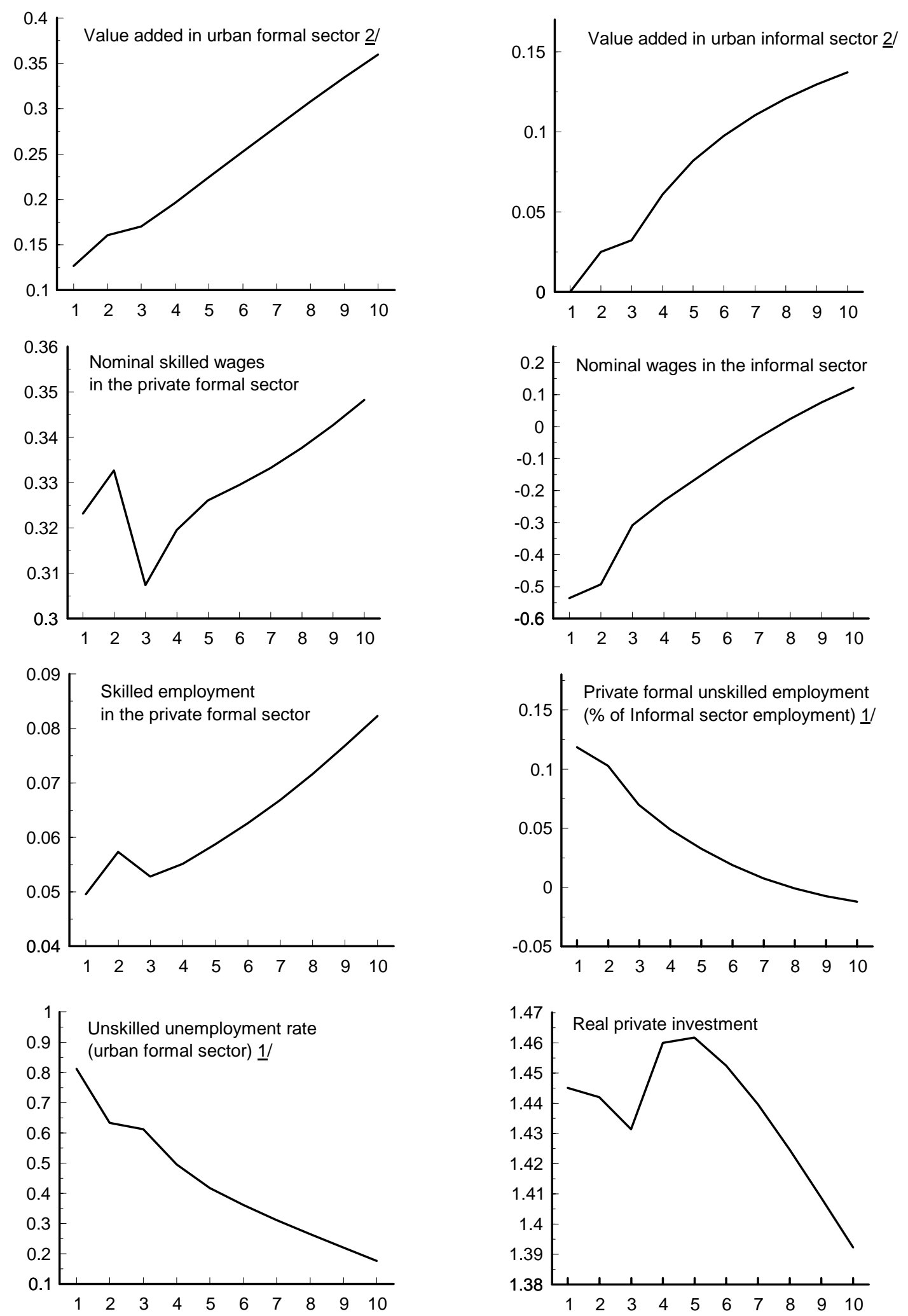

1/ Absolute deviations from base line. 2/ Real terms. 
Figure 7

Simulation Results

5 Percentage Points Reduction in Public Sector Skilled Labor Employment

(Percentage deviations from baseline, unless otherwise indicated)
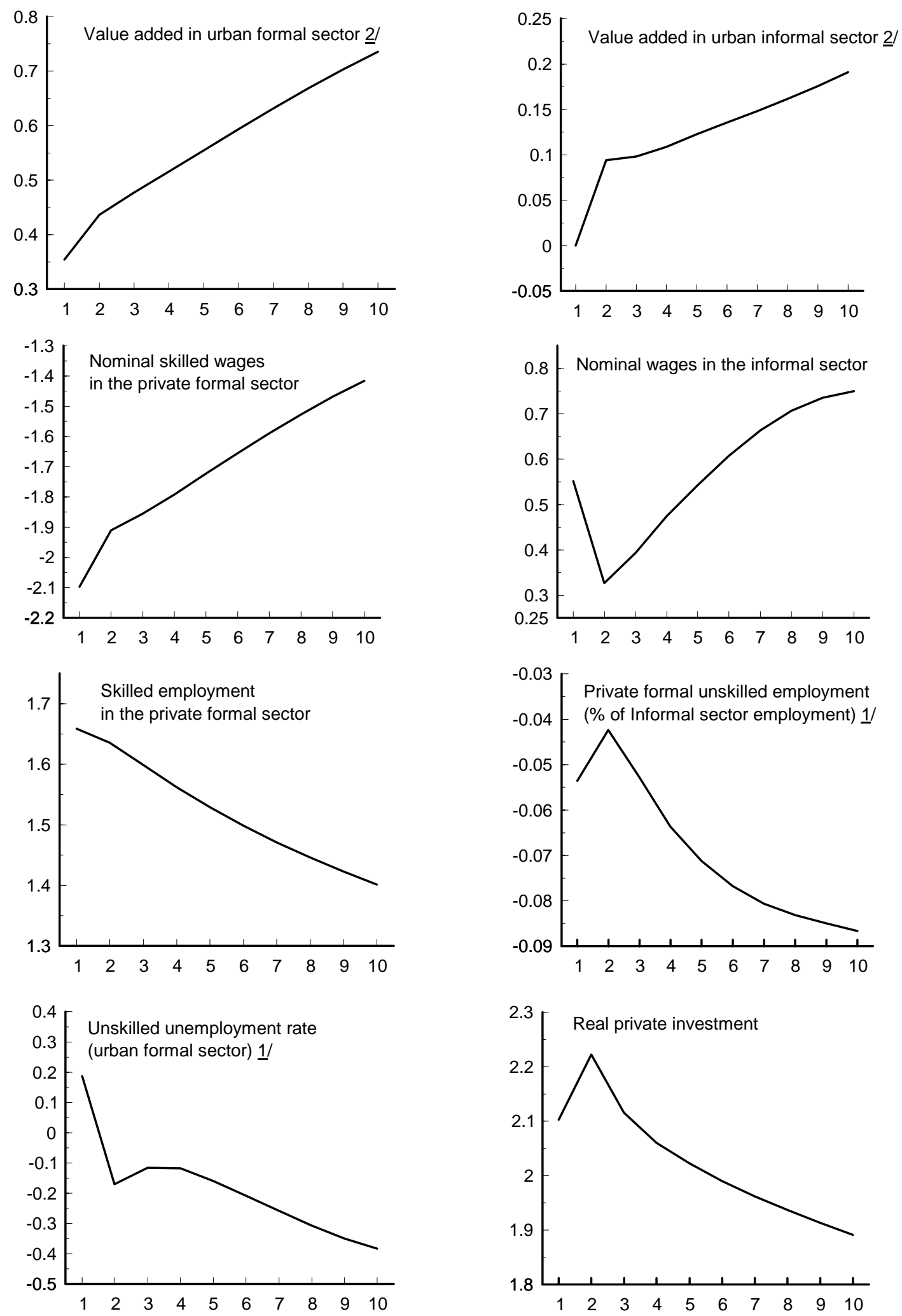

1/ Absolute deviations from base line. 2/ Real terms. 
Figure 8

Simulation Results

\section{Percentage Points Increase in Unskilled Labor Employment Subsidy (Percentage deviations from baseline, unless otherwise indicated)}

Non revenue neutral
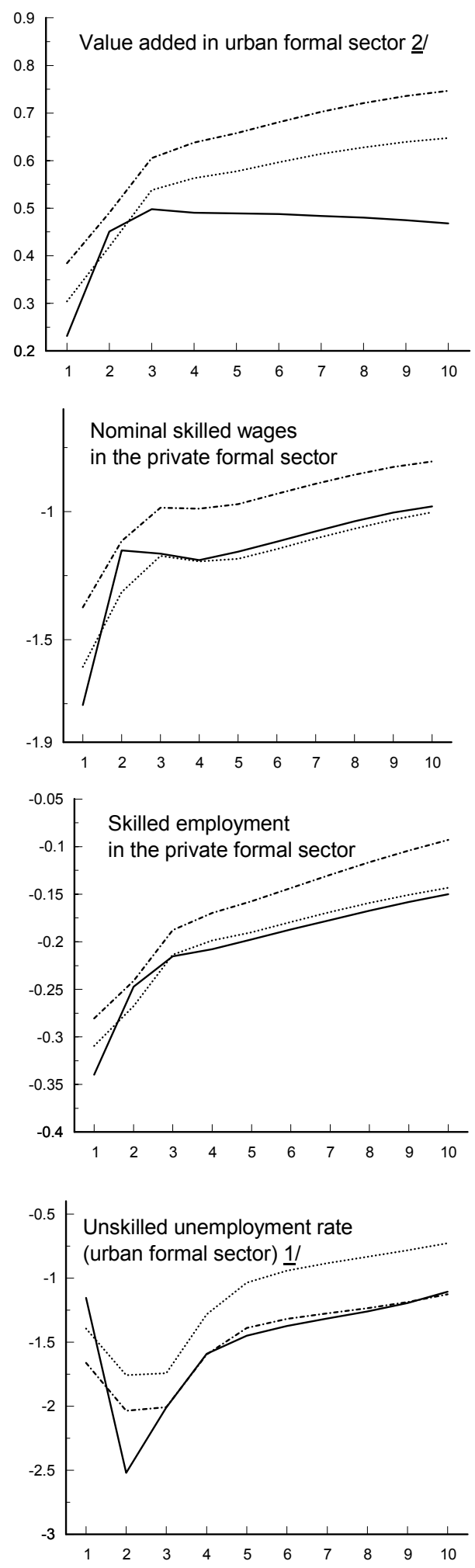

$1 /$ Absolute deviations from base line. 2/ Real terms.
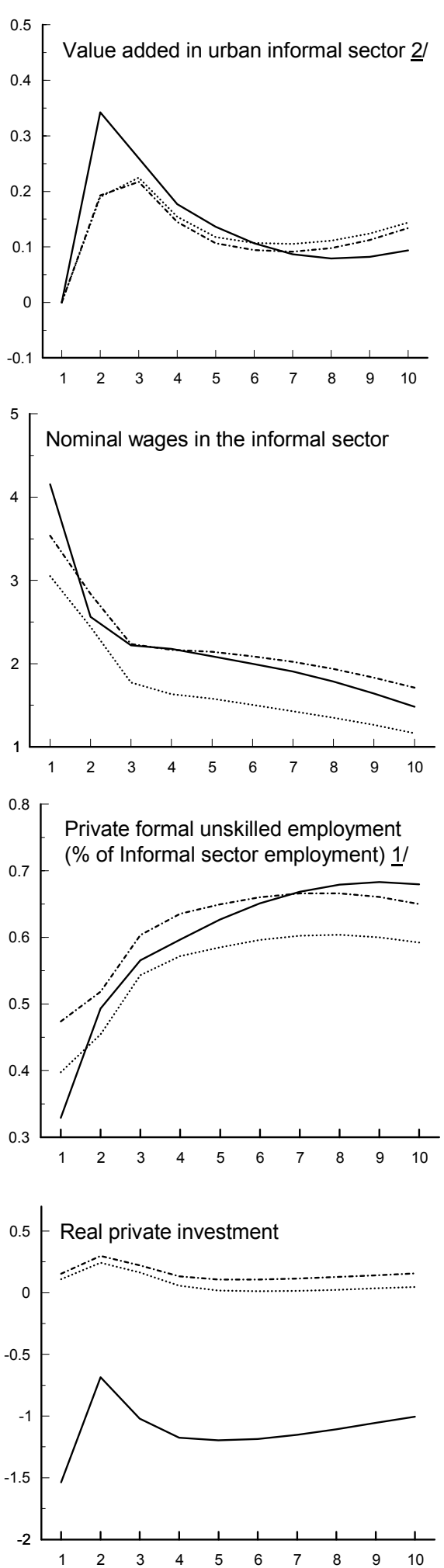
Figure 9

\section{Simulation Results}

Reduction in Labor Union's Bargaining Strength

(Percentage deviations from baseline, unless otherwise indicated)
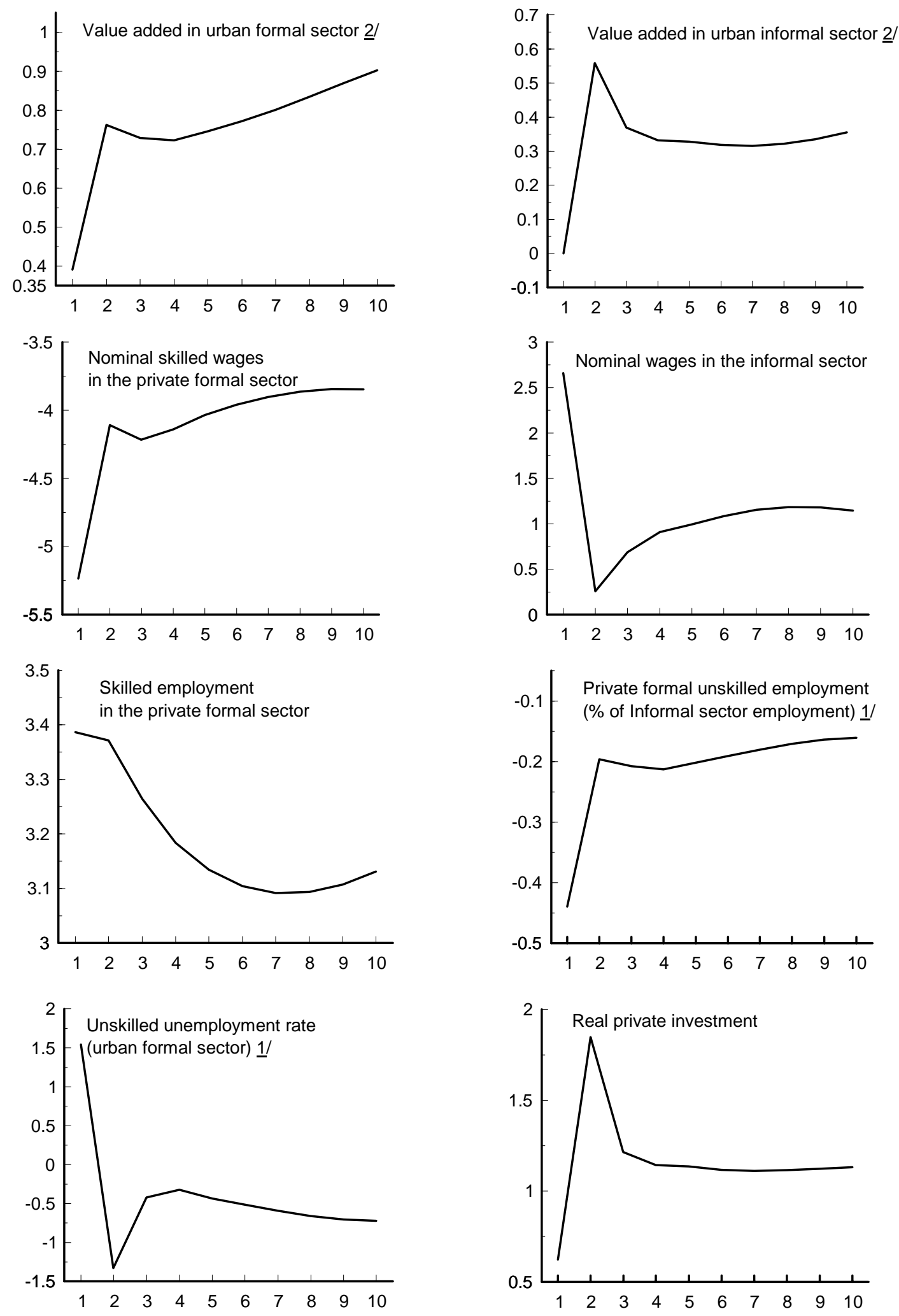

1/ Absolute deviations from base line. 2/ Real terms. 